Article

\title{
The Bigrlyi Tabular Sandstone-Hosted Uranium-Vanadium Deposit, Ngalia Basin, Central Australia
}

\author{
Susanne Schmid ${ }^{1, *}$, Wayne R. Taylor ${ }^{2}$ and Daniel P. Jordan ${ }^{2}$ \\ 1 CSIRO Mineral Resources, 26 Dick Perry Ave, Kensington, WA 6151, Australia \\ 2 Energy Metals Ltd., 28 Kings Park Rd, West Perth, WA 6005, Australia; wayne@energymetals.net (W.R.T.); \\ daniel@energymetals.net (D.P.J.) \\ * Correspondence: susanne.schmid@csiro.au
}

Received: 7 September 2020; Accepted: 6 October 2020; Published: 9 October 2020

\begin{abstract}
The Bigrlyi deposit is a tabular, sandstone-hosted, uranium-vanadium deposit of Carboniferous age located in the Ngalia Basin of central Australia. The deposit is similar to the continental, fluvial Saltwash-type of sandstone-hosted U-V deposits which are well known from the Colorado Plateau, USA. Most mineralization at Bigrlyi occurs as thin, multiple-stacked, stratiform lenses at the base of fluvial channels near the contact between a grey sandstone succession and a hematitic, purple-red sandstone succession. A larger halo of lower grade vanadium mineralization extends beyond the main $\mathrm{U}-\mathrm{V}$-mineralized zone. The host is an immature, feldspathic sandstone, grading into arkose and lithic-rich variants. Lithic 'rip-up' clasts of clay-rich sediments are common in the basal parts of fluvial channels, and are frequently the focus of, and have acted as sites for, U-V mineralization. Coffinite and uraninite are the main uranium minerals, with the former dominant. Vanadium is mainly hosted by Fe-V-bearing clays and chlorite, including roscoelite, grading into vanadian illite, the interlayer mineral corrensite, and altered detrital biotite. The $\mathrm{V}-\mathrm{Fe}-$ oxyhydroxide minerals montroseite, haggite and doloresite, and altered detrital Fe-Ti oxides, are minor V-hosts. Mineralized zones correlate with enrichments in $\mathrm{Se}, \mathrm{Li}, \mathrm{Ba}, \mathrm{Be}, \mathrm{Mo}$, $\mathrm{Mg}$ and $\mathrm{Fe}$, and elevated $\mathrm{Se} / \mathrm{S}$ ratios are characteristic of $\mathrm{U}$-mineralized zones. Petrographic studies show that a heterogeneous mixture of variably mineralized lithic clasts is present; in the same rock, some clasts are Fe-rich and only weakly U-V-mineralized, while other clasts are strongly V-and/or U-mineralized. These observations point to mineralization processes that did not take place in-situ in the host sandstone at the site of deposition as required by conventional groundwater models. Lead isotope results provide evidence of the open-system mobility of radiogenic elements in parts of the deposit. In V-bearing zones, radiogenic $\mathrm{Pb}$ contents were found to be unsupported by current $\mathrm{U}$ levels, suggesting that over time $U$ has been mobilized from these zones and redistributed, resulting in U-enrichment in other parts of the deposit. Mobility pathways were likely open over time from early in the history of the Bigrlyi deposit. A hybrid mineralization model, involving an interplay between solution-precipitation processes, detrital transport and post-depositional U remobilization, is proposed for Bigrlyi. Ferrous-ion-bearing clay minerals and pyrite are considered to be the most likely primary reductants/adsorbents, while the deposit is lacking carbonaceous matter.
\end{abstract}

Keywords: uranium-vanadium; tabular sandstone-hosted; Ngalia Basin; Carboniferous

\section{Introduction}

The Bigrlyi deposit is a tabular, sandstone-hosted, uranium-vanadium deposit of Carboniferous age located in the Ngalia Basin of central Australia [1]. Deposits of this style are distinct from 
classic roll-front deposits, and under the IAEA [2] classification scheme are usually assigned to the 'Saltwash-type' of sandstone-hosted uranium deposit. Such deposits are described as low-temperature, diagenetic-epigenetic-origin deposits associated with locally reduced facies of continental, fluvial sandstone successions (red-beds). Mineralization is stratiform and lensoidal in nature, and is typically bounded by less permeable horizons, which confines the deposit aquifer and later preserves the deposit from ingress of oxidized fluids. Reducing conditions within red-bed continental sandstones may arise from the presence of carbonaceous matter and/or Fe(II)-rich minerals such as chlorite or pyrite, microbial activity, or infiltrating sulfidic or hydrocarbon gases [3,4]. Some of the best examples of this deposit type are known from the Henry Basin and Uravan Mineral Belt districts of the Colorado Plateau. In these deposits it is believed that uranium was transported, in oxidized form, in surface- and groundwaters. Uranium was precipitated where these solutions encountered locally reducing conditions within the host sandstones $[4,5]$, and where adsorption onto clays, organic matter or oxide minerals occurred [6].

The distribution of U-V ore bodies of the Colorado Plateau is described as being mostly controlled by detrital carbonaceous material within the host Permo-Triassic-to-Jurassic red-bed successions [7]. Both primary (unoxidized) and secondary (oxidized) U-V ores are recognized amongst the Colorado Plateau deposits. The U-V mineralogy of unoxidized ore bodies comprise, among other minerals, uraninite, coffinite, vanadian illite-smectite, roscoelite, vanadian chlorite, montroseite and doloresite. The oxidized ore bodies, which have been affected by the percolation of meteoric waters, include various secondary $\mathrm{U}-\mathrm{V}$ minerals such as carnotite, tyuyamunite and pascoite [8]. The Bigrlyi deposit is mineralogically similar to these deposits, and both reduced and oxidized ores are recognized, though the former are dominant.

While uranium in the Colorado Plateau deposits is widely accepted as originating from the leaching of igneous rocks in the hinterland, the timing of vanadium mineralization and its source, and the nature of the mineralizing process, are all the subject of debate. Some authors favor mineralizing processes involving mixing between brine and meteoric water-dominant aquifers, while others emphasize the central role of fluid interactions with organic matter followed by diagenetic alterations of variable intensity [7,9-13]. All the deposit models assume that uranium and vanadium were transported to their sites of deposition in an oxidized state. However, there have been no petrographic studies of sandstone-hosted U-V deposits in the last 20 years; with the availability of more advanced microanalytical facilities, it is expected that modern studies will provide further insight into the mechanisms by which these deposits form.

Here we present a study on the Bigrlyi U-V deposit of the Ngalia Basin, central Australia, which is hosted in the Mount Eclipse Sandstone. Petrographic, mineralogical and geochemical evidence are provided to show the relationship between vanadium and uranium mineralization, and to describe the remobilization of these elements in the ore bodies.

\section{Geological Setting}

\subsection{Ngalia Basin}

The Ngalia Basin is an elongated, intracratonic basin of over $400 \mathrm{~km}$ east-west extent located in the southern part of the Northern Territory, central Australia (Figure 1). The basin is comprised of Neoproterozoic to Paleozoic sedimentary successions, which have a maximum thickness of about $5000 \mathrm{~m}$ [14] (Figure 1). The sedimentary units are discontinuous and are separated by unconformities due to various periods of uplift and erosion [15]. A complete Ngalia Basin sedimentary succession has not been identified in any one area [14]. Sedimentation was initiated at $\sim 850 \mathrm{Ma}$ when the Ngalia Basin was part of the much larger intracratonic Centralian Superbasin [16]. Aeromagnetic, gravity and seismic data have been used to construct the 3D architecture of the basin, which is characterized by a deep sub-basin in the northwest, an elongated trough in the east, and a structurally complex central uplift region $[17,18]$. The basin is bounded by numerous thrust faults, which are prominent on the 
northern basin margin, and high-angle reverse faults, which have resulted in half-graben structures in the interior of the basin. In cross-section, the sedimentary fill is wedge-shaped with the thickest sections located towards the northern basin margin [14].

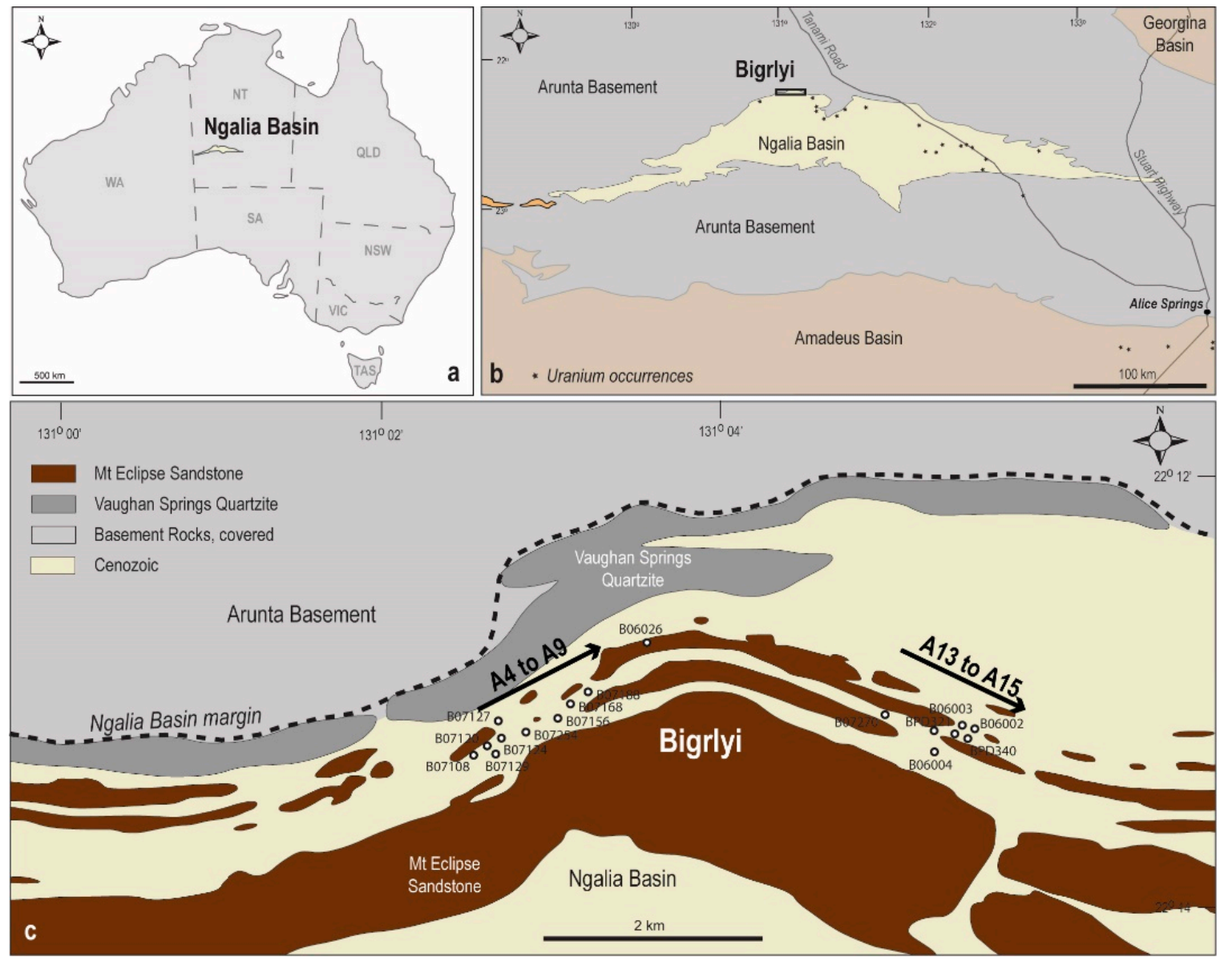

Figure 1. Ngalia Basin and Bigrlyi deposit location maps. (a) Ngalia Basin location in central Australia, (b) Bigrlyi deposit in relation to other uranium occurrences in the region, (c) map showing the location of the A4 to A9 and the A13 to A15 sub-deposit corridors, with drill cores studied.

The Ngalia Basin was affected by the long-lived intraplate Alice Springs Orogeny (ASO), which involved several tectonic movements over a period of $130 \mathrm{Ma}$ from the Late Ordovician to Late Carboniferous [16]. Tectonic events in the late Neoproterozoic and early ASO led to the isolation of the Ngalia Basin from other elements of the original Centralian Superbasin [19-21]. Late in the ASO, the basin was affected by a phase of N-S shortening that led to basin inversion, associated thrusting and folding, and uplift of the adjacent Proterozoic Arunta basement [16,19,22]. The Carboniferous Mount Eclipse Sandstone (MES) was deposited with angular unconformity on older basin units as a consequence of this event [16]. A detrital zircon U-Pb age spectrum from the MES [23] indicates that the major source of detritus was likely 1770 Ma age granites, including the proximal Carrington Suite and Yalgoolgarrie Granite, which outcrop to the north and east of Bigrlyi. Such sources are consistent with measured paleocurrent directions [18]. The MES is typically folded, forming broad synclinal and anticlinal structures, and is often tilted vertically or overturned at the basin margins and along internal basin structures; it is the only known host for U-V mineralization in the basin. The present-day maximum thickness of the MES is $2400 \mathrm{~m}[14,24]$. 


\subsection{Bigrlyi Deposit}

The Bigrlyi U-V deposit occurs over $11 \mathrm{~km}$ of strike length within steeply upturned beds of the MES; it was discovered by a ground scintillometer survey in 1973 as part of a targeted uranium exploration program in the Ngalia Basin [25]. Most U-V mineralization at Bigrlyi occurs as thin, multi-stacked, stratiform lenses in close proximity to the contact between a pyrite-bearing, grey sandstone unit and an underlying purple-to-red, variably oxidized, hematite-bearing sandstone. Additional mineralization occurs higher in the stratigraphy, near the upper contact between grey sandstone and overlying red-beds. Mineralized lenses are up to a few meters wide, and are typically $\sim 50-100 \mathrm{~m}$ in length with a distinct SW plunge. The Bigrlyi deposit has estimated mineral resources of approximately $10 \mathrm{kt}$ $\mathrm{U}_{3} \mathrm{O}_{8}$ at a grade of $0.13 \%$, and $20 \mathrm{kt} \mathrm{V}_{2} \mathrm{O}_{5}$ at a grade of $0.11 \%$, for a $0.05 \%$ cut-off level for both metal oxides [26].

The Bigrlyi deposit is divided into four major sub-deposits (from west to east): Anomaly-2 (A2), Anomaly-4 (A4), Anomaly-7/9 (A7/9) and Anomaly-13/15 (A15) (Figure 1). The A4 and A15 sub-deposits host most of the Bigrlyi uranium and both are predominantly reduced deposits in which the bounding impermeable units are carbonate-cemented beds and shales. A7/9 is a smaller vanadium-rich sub-deposit, and A2 is oxidized to a $>100 \mathrm{~m}$ depth and is carnotite-bearing. The sub-deposits are cut by a number of oblique faults with displacements of up to about $40 \mathrm{~m}$, which have disrupted, and in places, structurally thickened the mineralized zones. However, there is no evidence for structural control of mineralization.

The grey sandstone unit that hosts the majority of mineralization is a fluvial channel sequence dominated by medium-grained, immature arkosic sandstone with common interbeds of siltstone and shale and variable contents of calcite cement. Lithic clasts of mudstone and siltstone are locally common. The underlying variably oxidized purple-to-red sandstone, which is characterized by the presence of patchy, hematite-bearing mottles, is sedimentologically indistinguishable from grey sandstone and only hosts minor mineralization. The combined thickness of both units decreases from $\sim 280 \mathrm{~m}$ at A2 to the west to $<100 \mathrm{~m}$ at A15 in the east, and grey sandstone pinches out entirely east of A15. Fining upward cycles are well developed, typically defined by a basal erosional surface, which is bound by cross-stratified channel sandstone containing abundant mudstone 'rip-up' clasts and scattered pebbles of quartzite; trough cross-beds are common. Both, the grey and purple-red units are characterized by $\sim 10 \mathrm{~m}$ thick fining upward cycles with the tops of the cycles comprising fine micaceous sandstone overlain by either green siltstone (in grey sandstone) or red-brown siltstone (in purple-red sandstone), which commonly contain carbonate (calcrete) nodules and lenses at the very top of the cycle. The fine-grained units are interpreted to be abandoned channel tops [27].

The depositional environment is interpreted as a mature alluvial fan system comprising stacked fluvial channel sequences with occasional abandoned channel tops. The variation in color and mineralogy is related to the water saturation level in the channel fill due to the ephemeral nature of deposition. As such, the grey sandstone shows the development of early diagenetic kaolinite relative to illite in a fully water saturated channel, while hematite-bearing channels reflect variable water saturation with ongoing oxidation. Prolonged periods of aridity led to calcite precipitation due to evaporation [27].

Impressions and casts of fossil plant stems, trunks and other debris are locally present, especially in the finer grained channel sandstones [14]. However, unlike the Colorado Plateau U-V deposits, preserved carbonaceous matter is uncommon at Bigrlyi and is rarely found despite some earlier reports to the contrary [25]. Further east in the Ngalia Basin, carbonaceous and coaly shales have been intersected by shallow drillholes into the MES, but these units are not strongly mineralized [14,28].

\section{Materials and Methods}

Sampling and portable X-Ray Fluorescence (pXRF) spot analyses of drill core using an Olympus-InnovX Delta instrument were carried out during on-site visits to Energy Metals' Bigrlyi 
exploration camp and core yard. However, although standards were monitored, no matrix-specific calibration was carried out and values should only be used as indicators of relative abundance.

Polished thin sections were prepared for a range of samples of various mineralization styles and were characterized at CSIRO's micro-analytical facilities in Perth, Australia. A Zeiss AxioImager semi-automated petrographic microscope was used for the routine acquisition of plane-polarized, cross-polarized and reflected light imagery with a resolution of $2.5 \mu \mathrm{m}$. Selected sections were scanned with a Bruker Tornado M4 X-Ray Fluorescence (XRF) element mapper using a spot resolution of $25 \mu \mathrm{m}$.

To provide detailed petrographic, mineralogical and element distribution information, polished sections of drill core were examined using a Phillips XL40 Scanning Electron Microscope (SEM) with an attached Bruker energy dispersive X-ray spectroscopic system (EDS) and cathodoluminescence (CL) detector, and a Zeiss Field Emission Gun Scanning Electron Microscope (FEG-SEM) equipped with a Bruker EDS system. Backscattered electron (BSE) images, EDS element maps, CL images and composites of these were used to characterize the samples.

Multi-element geochemical data for Bigrlyi samples were extracted from Energy Metals' extensive in-house validated exploration database. Whole-rock major and trace element geochemical analyses (101 samples) were undertaken by commercial laboratories ALS Global and Labwest Minerals Analysis using low detection limit four-acid digest and lithium-borate-fusion ICP-MS methods monitored by certified standards. Organic carbon ( 240 samples) was determined by acid leach/combustion furnace analysis.

Lead isotopic compositions (63 samples) were determined by commercial laboratories ALS Global and Labwest Minerals Analysis using four-acid digest HR-ICP-MS methods, in which special analytical procedures were used to eliminate ${ }^{204} \mathrm{Hg}$ mass overlap. Accuracy and precision were monitored by certified $\mathrm{Pb}$-isotope standards and by Energy Metals' internal standards. Pb-isotope ratios measured for Energy Metals' EMST22 standard over several sample batches gave values ( $\pm 1 \sigma$ precision) of ${ }^{206} \mathrm{~Pb} /{ }^{204} \mathrm{~Pb} 187 \pm 3,{ }^{207} \mathrm{~Pb} /{ }^{204} \mathrm{~Pb} 25.3 \pm 0.2 \mathrm{and}{ }^{208} \mathrm{~Pb} /{ }^{204} \mathrm{~Pb} 40.4 \pm 0.5$.

X-ray Diffraction (XRD) patterns of 22 powdered samples were collected on whole-rock geochemistry sample pulps with a Bruker D4 Endeavor instrument fitted with a Co tube, Fe filter, and a Lynxeye position-sensitive detector. The measured 2-theta range was $5-90^{\circ}$ (or $50^{\circ}$ ), with a step size of $0.02^{\circ}$ and a divergence slit of $1^{\circ}$.

Supporting data and further information is provided in the Supplementary Materials.

\section{Results}

\subsection{Features of the Host Sandstone}

The host sandstone is dominantly a feldspathic sandstone (subarkose) with 10-25\% K-feldspar content, grading into arkose and lithic-rich variants. Textures range from grain-supported to matrix-supported with a variable content of clay matrix, lithic clasts and carbonate cement. The dominant detrital minerals are quartz and K-feldspar. The quartz grains are angular to sub-angular and partially interlocked. The K-feldspar grains, which consist mainly of microcline, are also angular and often fractured. Other detrital minerals include variably degraded or chloritized biotite, muscovite, roscoelite grading into vanadian illite, chlorite, dolomite and rare plagioclase. Heavy mineral detrital grains comprise zircon, monazite, apatite, rutile/leucoxene, $\mathrm{Fe}-\mathrm{Ti} \pm \mathrm{V}$-oxides, tourmaline and garnet.

Lithic clasts are present in a variety of forms. Scattered rounded pebbles and cobbles are common throughout the MES, and consist dominantly of quartzite with less abundant sandstone, granite, quartz-muscovite schist and phyllite, limestone and dolostone. They are likely derived from fully lithified, underlying sedimentary units of the Ngalia Basin, as well as the adjacent Proterozoic basement. Lithic 'rip-up' clasts of fine-grained sedimentary rocks, comprising mudstone (shale), siltstone, sandstone, occasional micritic carbonate and composites of these, are abundant at the base of fining-upward sedimentary cycles. They are typically of irregular or elongate form due to apparent soft-sediment deformation, and may be 'smeared out' and grade into clay-rich matrix. The clasts 
range from a few millimeters up to $40 \mathrm{~cm}$ in size and are likely derived from partly lithified sediments within the fluvial system. Rip-up clasts of fine-grained sedimentary rocks are frequently the focus of, and have acted as sites for, U-V mineralization.

The clay-rich matrix, grading into mudstone rip-up lithic clasts, may be a significant component of the host sandstones. A detailed study of the clay mineralogy has shown that a complex mixture of discrete clay species is present. The clay minerals include kaolinite, chlorite, illite and smectite, together with the interstratified species corrensite (chlorite-smectite) and illite-smectite $[18,27,29]$. The abundances of kaolinite and corrensite usually dominate over illite and chlorite in grey sandstone.

Pyrite is the main Fe-sulfide and is common in the clay-rich matrix, where it typically occurs as fine grains of globular form, as framboidal aggregates, discrete subhedral to euhedral grains, and as zoned or skeletal forms; pyrite is also associated with degraded biotite, where it may decorate cleavage planes, and as a partial replacement product of detrital Fe-Ti oxides. Marcasite is occasionally present as interstitial aggregates intergrown with pyrite, but at Bigrlyi there is no apparent spatial relationship between marcasite and mineralization, as is characteristic of the ore zones of some Colorado Plateau U-V deposits, for example [30].

Calcite is an authigenic mineral occurring as interstitial calcite cement. The cement is variable and patchy in distribution, but in some cases may flood and occlude all available pore space. Ore minerals are sometimes found enclosed by carbonate cement, indicating they formed prior to early diagenetic cementation. A detailed description and discussion of the diagenetic history can be found in Schmid and Quigley [27].

\subsection{Distribution of $U-V$ Across the Deposit}

The distributions of uranium and vanadium, as well as calcium, have been investigated across the deposit using an extensive dataset of drillhole-derived data that includes downhole geochemical assays and gamma-ray logs. Calcium has been used as a proxy for calcite to better understand the distribution of cemented sandstone. Drillhole assay data for $\mathrm{V}_{2} \mathrm{O}_{5}, \mathrm{U}_{3} \mathrm{O}_{8}$ and Ca were compiled and composited to 1 meter intervals downhole, producing some 25,300 records. A plot of $\mathrm{U}_{3} \mathrm{O}_{8}$ versus $\mathrm{V}_{2} \mathrm{O}_{5}$ concentrations on this basis (Figure 2) shows that the Bigrlyi deposit is dominated by vanadium-rich but uranium-poor intervals, with $90 \%$ of the assayed meter intervals being of this type, but overall $\mathrm{U}$ and $\mathrm{V}$ are well correlated. 


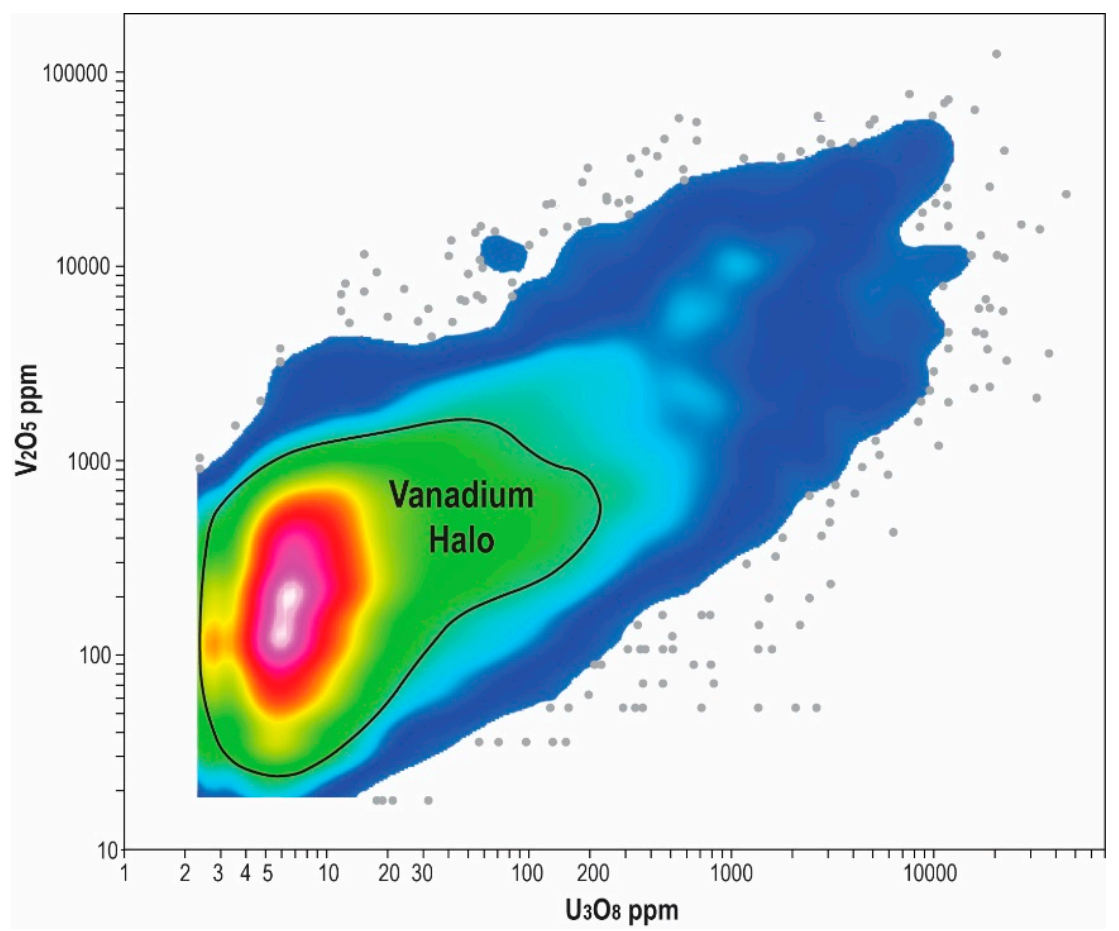

Figure 2. Density data plot showing the variation in $\mathrm{V}_{2} \mathrm{O}_{5}$ versus $\mathrm{U}_{3} \mathrm{O}_{8}$ assay values for 1 meter composited drillhole intervals covering the entire Bigrlyi deposit (25,300 meter-intervals in total). The tvanadium-rich halo is associated with vanadium levels in the hundreds of ppm (up to about 2000 ppm $\mathrm{V}_{2} \mathrm{O}_{5}$ ) but $<200$ ppm $\mathrm{U}_{3} \mathrm{O}_{8}$.

Visualization of this data in three dimensions shows that the deposit is defined by a large halo of $\mathrm{V}$ mineralization (Figure 3), which surrounds U-rich intervals, and occupies a volume more than three times larger than the U-mineralized volume. The halo is characterized by $\mathrm{V}_{2} \mathrm{O}_{5}$ values in the hundreds of ppm range (median 200 ppm $\mathrm{V}_{2} \mathrm{O}_{5}$ ), but with low $\mathrm{U}$ contents. For U-mineralized intervals above the 100 ppm $\mathrm{U}_{3} \mathrm{O}_{8}$ level, the median $\mathrm{V}_{2} \mathrm{O}_{5}: \mathrm{U}_{3} \mathrm{O}_{8}$ weight ratio for all Bigrlyi mineralization is 3.8. The Bigrlyi deposit contains a significant number of meter intervals of elevated $\mathrm{V}$ concentrations, with over $5 \%$ of the dataset falling in the $0.2 \% \mathrm{~V}_{2} \mathrm{O}_{5}$ to $12 \% \mathrm{~V}_{2} \mathrm{O}_{5}$ range. The maximum meter-interval $\mathrm{U}$ concentration is $4.5 \% \mathrm{U}_{3} \mathrm{O}_{8}$.

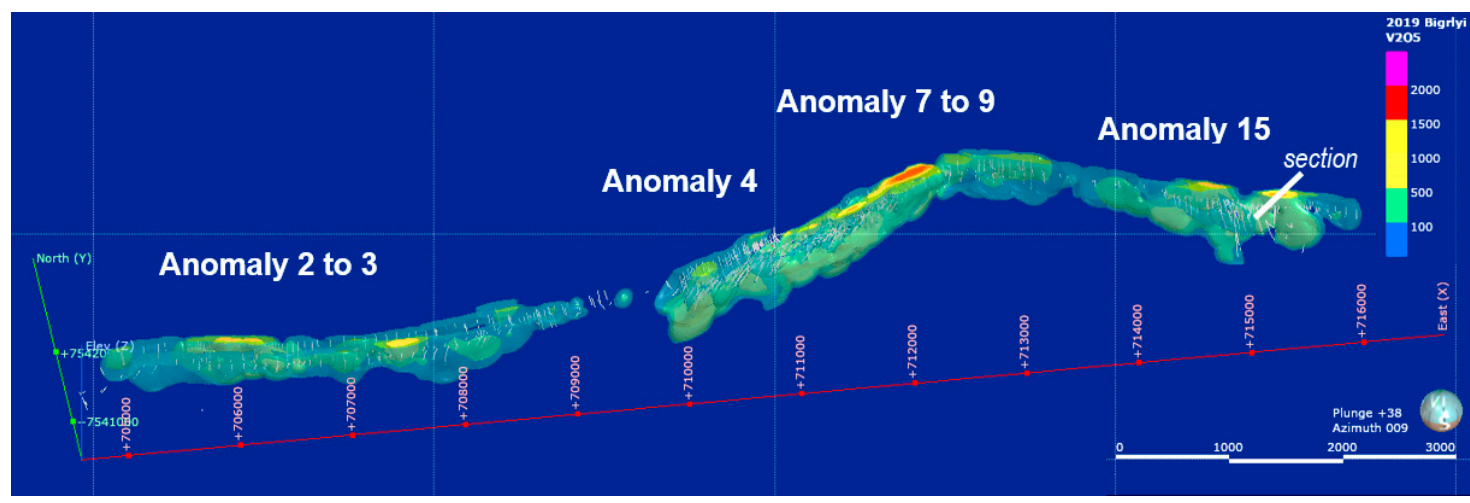

Figure 3. Three-dimensional model (spheroidal interpolated Leapfrog model) showing the distribution of $\mathrm{V}_{2} \mathrm{O}_{5}$ mineralized shells (colors indicate grade in ppm $\mathrm{V}_{2} \mathrm{O}_{5}$ ) across the Bigrlyi deposit, oblique view to north.

In terms of spatial variation, the distribution of $U$ relative to $V$ varies with each sub-deposit along the strike; in particular, the A4 sub-deposit is characterized by low V:U and is host to nearly $60 \%$ of the 
total uranium in the Bigrlyi deposit, whereas the adjacent A7/9 sub-deposit is V-rich (Figure 3) with high $\mathrm{V}: \mathrm{U}$, and hosts over $30 \%$ of vanadium in Bigrlyi. Typical features of the U-V-Ca distribution modeled in 3D (Figure 4) support the drillhole observations showing that the mineralization is stratiform in nature, and largely confined within steeply-dipping grey sandstone, with U mineralization concentrated near the upper and lower contacts; the V-rich halo within grey sandstone and the surrounding envelope of calcite-cemented sandstone is evident.

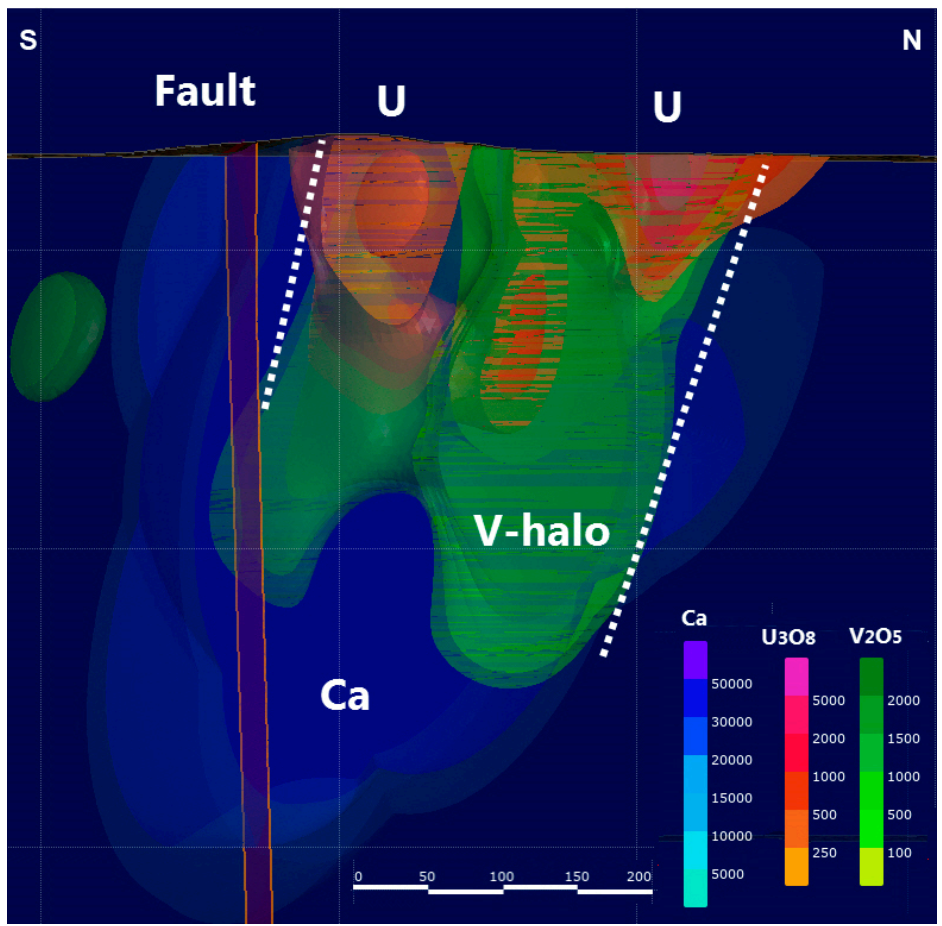

Figure 4. Three-dimensional model showing the distribution of $\mathrm{U}, \mathrm{V}$ and $\mathrm{Ca}$ in a cross-section through Anomaly-15 (see Figure 3 for location). U mineralization shells in red, V mineralization shells and the V-halo in green, and the Ca-rich envelope (calcite-cemented sandstone) in blue. The white dashed lines show the steeply dipping upper and lower stratigraphic contacts of host grey sandstone, and the red vertical line is a modeled fault plane. The depth of the section below surfaces as shown is approx. $250 \mathrm{~m}$.

Because stratigraphic correlations across fluvial channels in an alluvial fan are difficult to make due to the lateral migration of the channels, a distinctive playa marker horizon (i.e., calcareous mudstone with nodular calcrete) was used as the datum for correlation. The horizon lies stratigraphically above the mineralization, and was identified based on gamma ray data and core logging. The distribution of mineralization for a transect from the A4 to A7 sub-deposits, corrected for stratigraphic level, shows that the bulk of mineralization is hosted in the basal interval of the stacked channel system about 120 to $150 \mathrm{~m}$ below the deposit-wide marker horizon (Figure 5). 


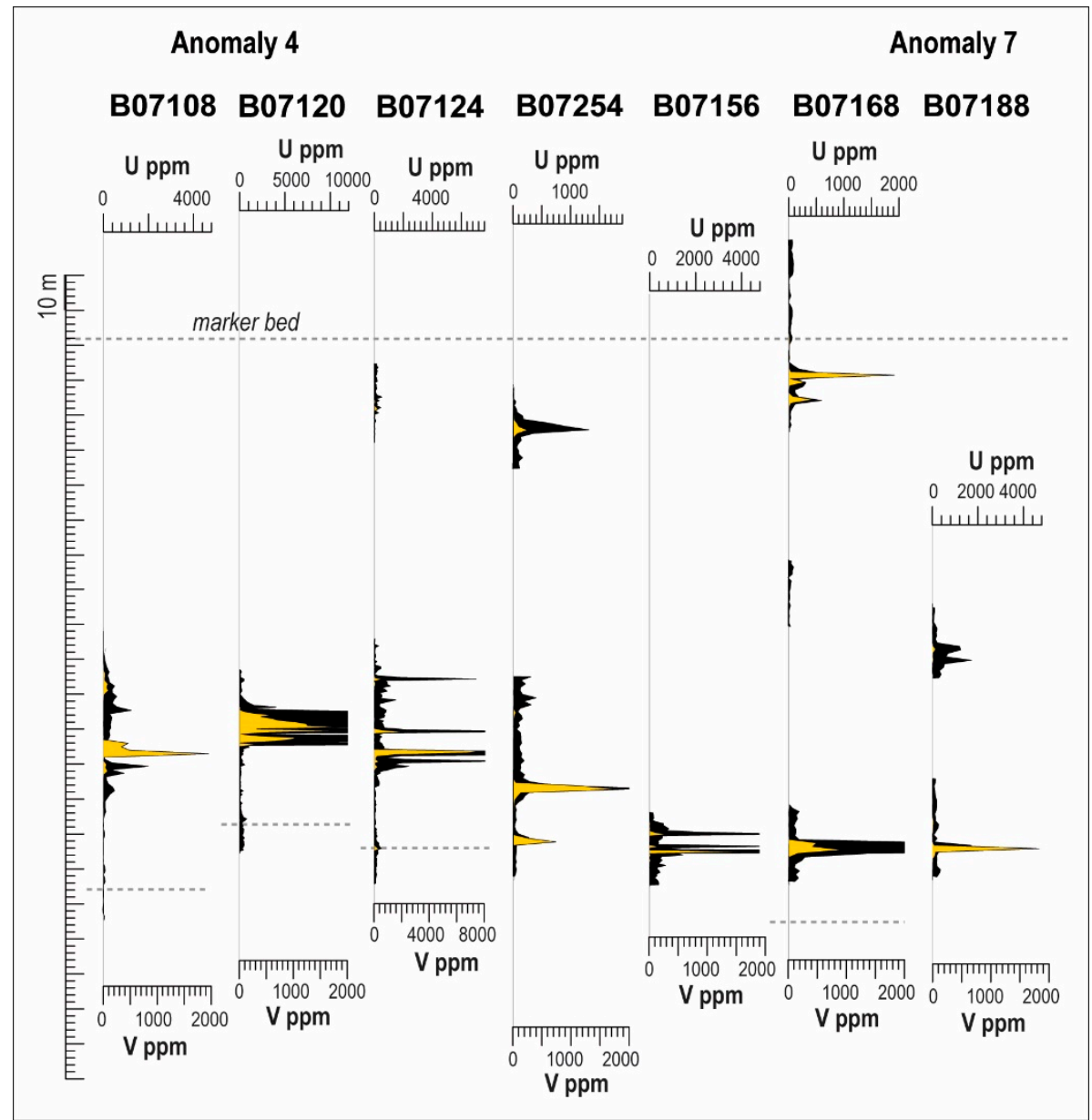

Figure 5. Distribution of mineralization for a transect from the A4 to A7 sub-deposits corrected for stratigraphic level using the upper marker bed (grey dashed line). Uranium abundance in yellow, vanadium abundance in black.

\subsection{Distribution of $U-V$ in Drill Core and Its Relation to Sedimentology}

The distribution of U-V mineralization was investigated in the context of sedimentary facies variations and cyclicity. The fining upward cycles are capped by calcite-cemented, fine-grained sandstone and siltstone at the cycle tops, which creates a relative permeability and porosity barrier. In order to show the association between facies and U-V mineralization, a series of spot geochemical measurements was undertaken on drill core using a portable XRF (pXRF).

\subsubsection{Drill Core-B07120}

A set of pXRF measurements was taken across a mineralized zone over a core interval of $14 \mathrm{~m}$ (Figure 6). The interval is associated with intense calcite cementation enveloping the mineralization. Visual observations were confirmed by the geochemical measurements, which show elevated Ca (20-23\% as calcite cement) on either side of the mineralization (Figure 6). The mineralized zone is defined by elevated V (4510 ppm) and U (3973 ppm), as well as $\mathrm{Fe}(1.6 \%)$ and $\mathrm{Al}(6.8 \%)$ concentrations, due to the abundance of phyllosilicates. 


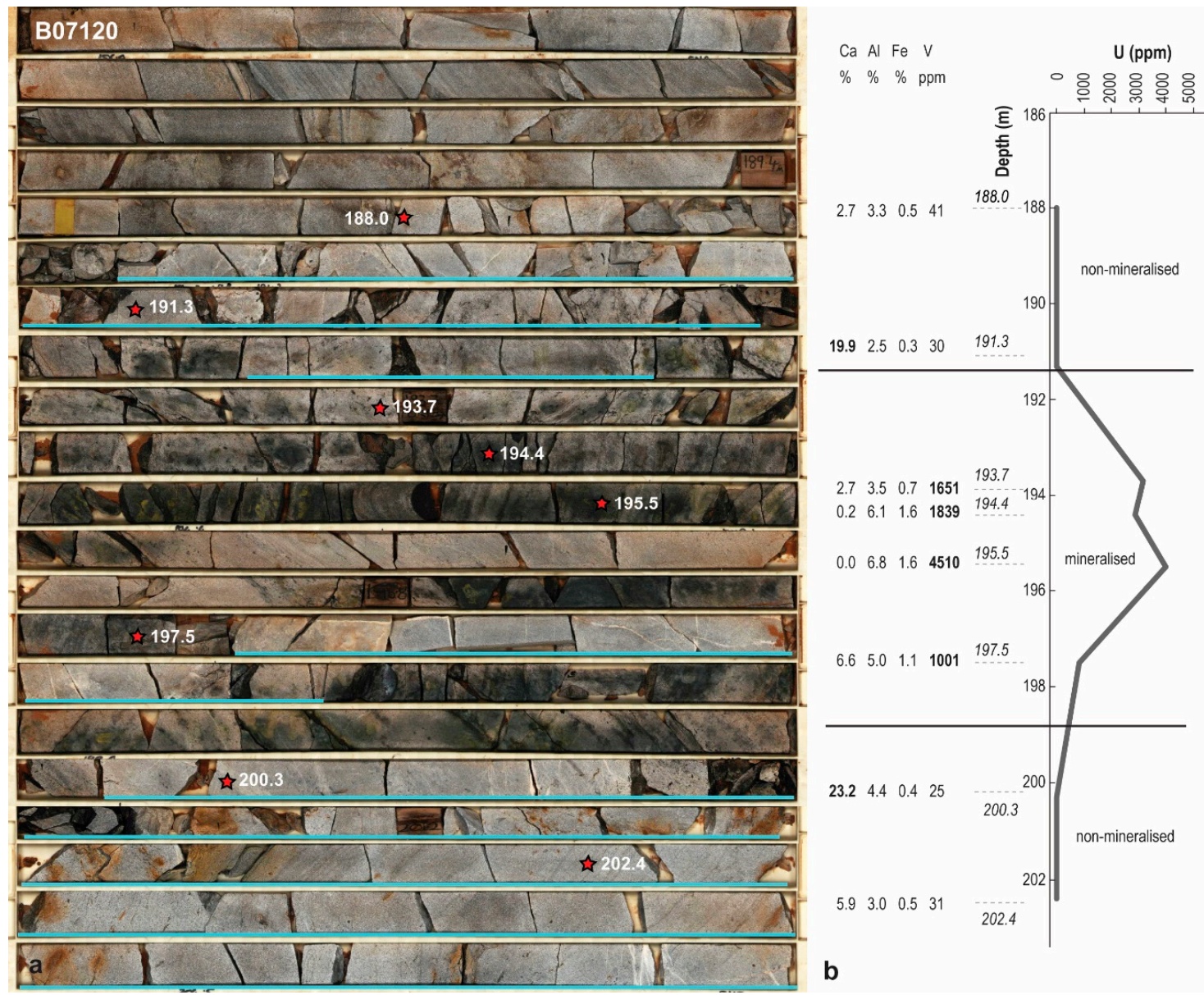

Figure 6. (a) Hole B07120 (A4) drill core imagery over a U-V-mineralized; (b) interval showing pXRF measurements at selected points between 188.0 and $202.4 \mathrm{~m}$ depths. Dark sandstone of sooty appearance in drill core is typical of $\mathrm{V}$ mineralization.

\subsubsection{Drill Core-B07129}

A set of pXRF measurements was taken over a $\sim 40 \mathrm{~cm}$ interval within a mineralized zone across an erosional contact (Figure 7). The interval below the contact is a medium- to fine-grained grey sandstone with a very thin micaceous top (contact). The measurement $10 \mathrm{~cm}$ below the contact is weakly V-mineralized (367 ppm), with relatively low U (44 ppm). The base of the overlying cycle comprising pink-grey arkosic sandstone shows a sharp increase in U-V mineralization (U 2184 ppm, V $809 \mathrm{ppm}$ ). Approximately $10 \mathrm{~cm}$ above the contact, the sandstone is black and sooty in appearance due to strong enrichment in $\mathrm{V}$ (5851 ppm), while U concentrations are unchanged from the interval below. It is noticeable that the Fe concentrations also increase with $\mathrm{V}$, which correlates with a relative enrichment of phyllosilicates, as seen visually (Figure 7). 


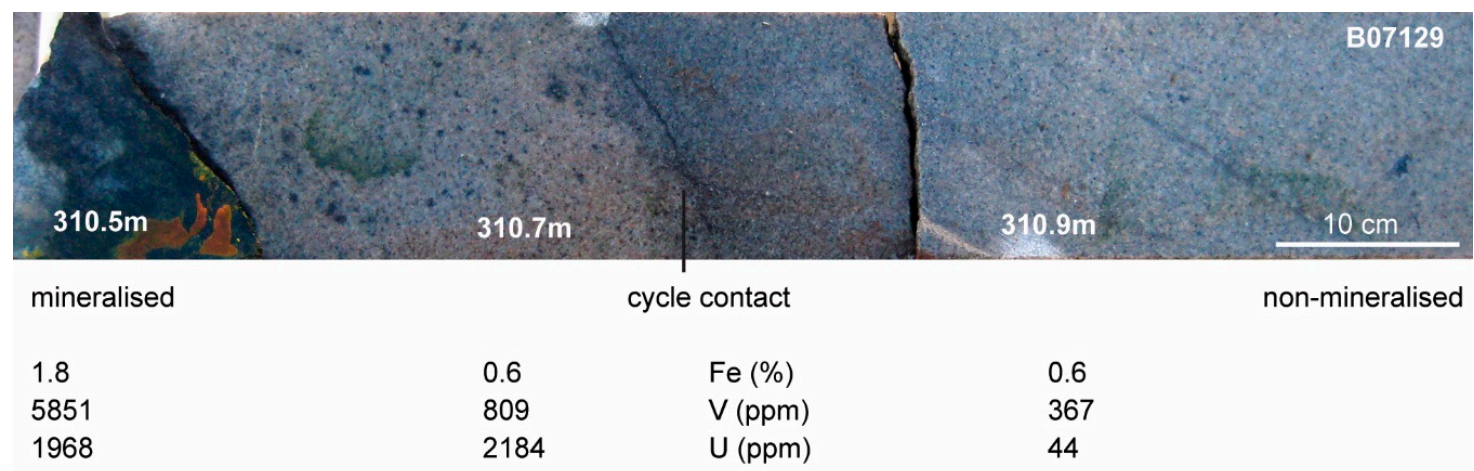

Figure 7. Portable XRF measurements across a cycle contact (drill core B07129-A4) at an erosional surface with the U-V-mineralized zone occurring in coarse-grained, arkosic sandstone just above the channel base. Elevated V levels are present in fine-grained sandstone of the underlying cycle top (V-halo).

\subsection{Mineralogy and Petrology}

To investigate U-V mineral associations, mineralized and non-mineralized intervals were studied in more detail. Powder XRD results show that samples of host sandstone without mineralization are composed of quartz, K-feldspar (microcline), muscovite, biotite, illite, kaolinite, calcite, and chlorite/corrensite, with traces of dolomite, pyrite and hematite (in partly oxidized sandstone). Samples dominated by U-V mineralization contain in addition to the above coffinite, uraninite, montroseite and roscoelite. Samples dominated by $\mathrm{V}>\mathrm{U}$ mineralization were also found to contain, in addition to montroseite, the vanadium oxide-hydroxide minerals haggite and doloresite (see Supplementary Materials Figure S1). The mineralogy was further refined by petrographic investigations.

\subsubsection{Uranium-Dominated U-V Mineralization}

Uraninite and coffinite are the predominant uranium minerals, and are mainly concentrated in clay-rich lithic clasts and the clay-rich matrix (Figure 8a). QEMSCAN (automated mineralogical analysis) studies of mineralized samples indicate that coffinite is generally the dominant species, with the uraninite to coffinite ratio varying from about 1:1 to 1:4 [31]. Uraninite typically occurs as fine-grained, irregular or globular aggregates, as disseminations intergrown with clays (Figure 8a,b), and with chloritized/degraded biotite in association with montroseite (Figure 8c). Uraninite may also rim and partly replace detrital rutile and Fe-Ti-V oxide grains (Figure $8 \mathrm{a}, \mathrm{f}$ ), and may be found as a replacement product of early-formed pyrite. Coffinite characteristically encrusts the margins of quartz grains (Figure $8 \mathrm{a}, \mathrm{b}$ ) and degraded biotite; in more porous samples it coats grain contacts and internal fractures within K-feldspar (Figure 8d,e). Coffinite may encase or replace fine globular-textured uraninite leaving disc-shaped remnants (Figure $8 b$ ). Galena is a common fine-grained inclusion in coffinite, which likely reflects the exsolved former radiogenic $\mathrm{Pb}$ solid-solution content.

Detrital Fe-Ti-oxide grains have undergone a process of replacement by $\mathrm{V}$ and $\mathrm{U}$ (Figure 8f). Element mapping shows the pervasive replacement of Fe by $\mathrm{V}$ on the grain margins and along internal fractures; there is growth of uraninite crystallites on the grain rims, and infiltration of fine uraninite into V-enriched areas along micro-scale fractures.

Under cathodoluminescence (CL) imaging, radiation-induced damage is noticeable on K-feldspar grains, and to a lesser extent on quartz grains, where zones of quenched CL emissions on grain rims and internal fractures are related to the proximity of uranium minerals (Figure 8e). Of particular interest in Figure 8e is the presence of obvious radiation-induced damage affecting K-feldspar and quartz, where no uranium mineralization is currently visible (left-hand part of Figure 8e). 

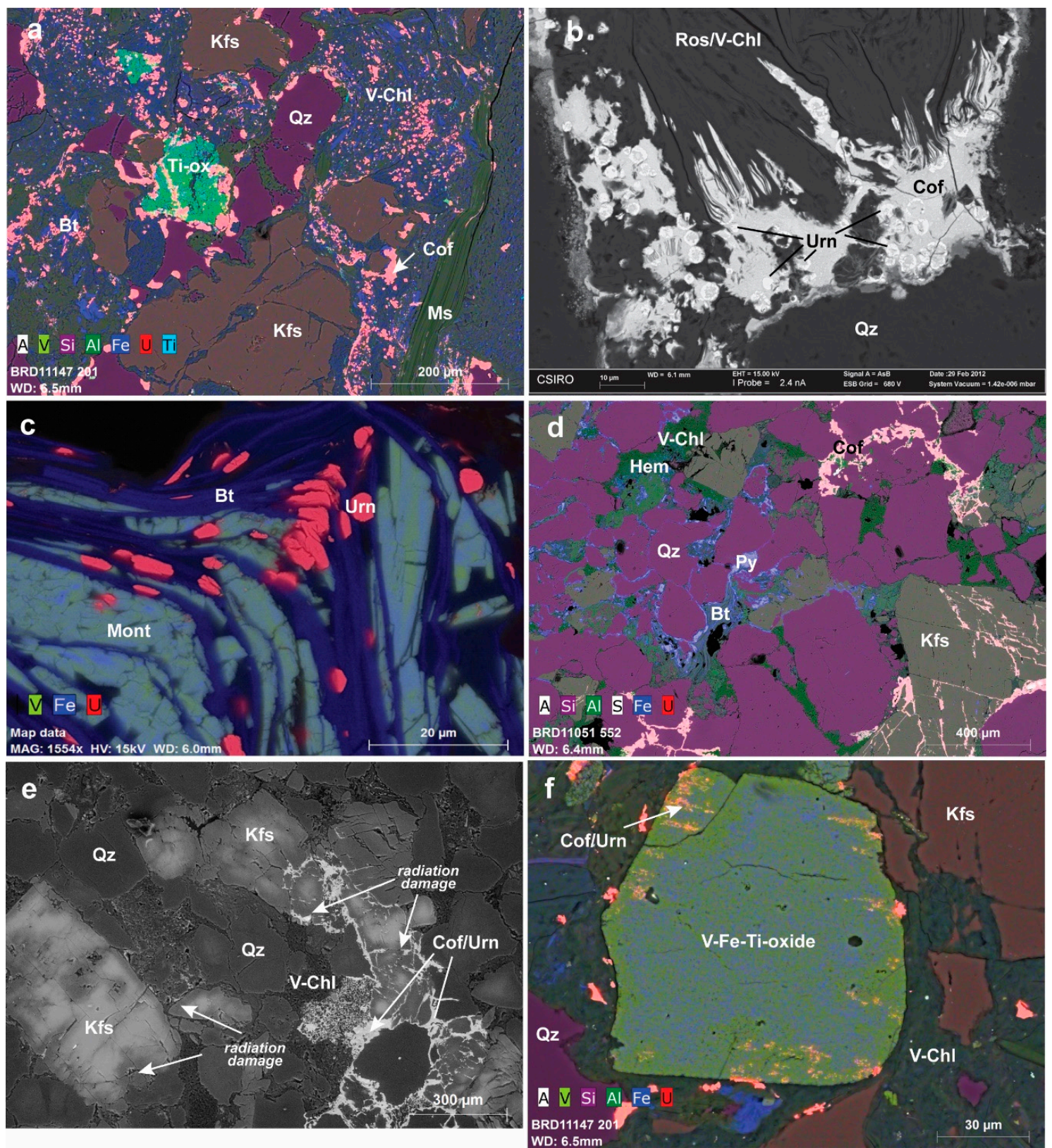

Figure 8. BSE-EDS micrographs illustrating U-mineral textures. (a) Fine, disseminated uraninite/coffinite (pink) resides within Fe-clay-rich matrix and partly replaces Fe-Ti-V oxides (green); coffinite also replaces the margins of quartz grains; (b) on a quartz-mica grain contact, coffinite (light grey) replaces quartz and invades mica cleavage planes; globular uraninite has been partly replaced by coffinite leaving disc-shaped remnants of about 5 microns diameter; (c) uraninite crystallites (red) decorate the cleavage planes of altered biotite (dark blue) in association with bladed montroseite crystals (light blue-green); (d) coffinite (pink) fills fractures in K-feldspar and replaces the margins of some quartz grains; fine pyrite (light blue) occurs separately from coffinite mainly within the clay-rich matrix and as thin coatings on some grain boundaries. (e) Composite CL/BSE image showing strong radiation damage features in fractured K-feldspar; the absence of fracture-filling uranium minerals in part of the section indicates loss of $\mathrm{U}$; (f) detrital Fe-Ti oxide grain showing partial replacement by $\mathrm{V}$ and U (Ti not shown in Figure). 


\subsubsection{Vanadium-Dominated U-V Mineralization}

Vanadium-uranium mineralization at Bigrlyi is primarily associated with the clay-rich matrix, with clay-rich lithic clasts, and with detrital micas and chlorite imbedded in the matrix. The main V-host minerals are Fe-V-bearing clays and chlorite, including roscoelite grading into vanadian illite, corrensite and smectite, plus altered biotite, where vanadium occurs as a solid-solution component. Vanadium is also hosted in the V-Fe-oxyhydroxide minerals montroseite, doloresite and haggite, and may be present as a component of altered Fe-Ti oxides and rutile/leucoxene. Texturally, montroseite occurs within the clay-rich matrix as disseminated bladed crystals grading into massive aggregates of fine-grained, bladed montroseite up to a few millimeters across. Montroseite also occurs as crystal aggregates replacing altered/chloritized detrital biotite (Figure 8c). Montroseite is locally associated with pyrite, uraninite/coffinite and rutile/leucoxene. Occasional zoned pyrite grains intergrown with montroseite are found imbedded within the matrix.

QEMSCAN studies of V-U-mineralized samples confirm that vanadiferous phyllosilicates are the dominant $\mathrm{V}$-hosting species. In a representative $\mathrm{V}>\mathrm{U}$ ore material containing $0.5 \% \mathrm{~V}_{2} \mathrm{O}_{5}$ and $0.1 \%$ $\mathrm{U}_{3} \mathrm{O}_{8}$ from the $\mathrm{A} 4$ sub-deposit, the ratio of vanadiferous aluminosilicates to montroseite was found to be $\sim 3: 1$, with about half the vanadium being associated with V-chlorite/corrensite [31]. In agreement with petrographic observations, V-bearing detrital biotite is more abundant in the coarse fractions, whereas the opposite is true for chlorite/corrensite and montroseite. QEMSCAN inter-mineral correlations indicate that montroseite has a strong association with both vanadiferous biotite and chlorite.

On the thin-section scale, optical and XRF elemental mapping studies of $V>U$-mineralized sandstones show that lithic rip-up clasts may host a significant proportion of U-V mineralization. Mineralized samples from drill core B07270 (A15 sub-deposit), for example, contain a texturally and chemically heterogeneous mixture of different kinds of deformed lithic clasts, including mudstone, siltstone and fine-to-coarse grained sandstone (Figure 9). The clasts are heterogeneous with respect to the distribution of mineralizing elements, and U-V-Fe concentrations are highly variable; some clasts are Fe-rich and only weakly U-V-mineralized, while other clasts are strongly V-and/or U-mineralized. A proportion of clasts are chemically zoned and/or are composites containing variably enriched Fe, $\mathrm{V}$ and $\mathrm{U}$ domains (Figure 10a). Some clasts are also distinct in that they are rich in heavy mineral content or may contain patches of calcite cement, features that reflect their diverse origins. Compared to the lithic clasts, the sandstone matrix in these specimens is minimally mineralized; U-V-Fe mineralization is scattered amongst interstitial clay pockets that likely represent disaggregated particles abraded from the larger clasts.

In the example shown in Figure 9, the various lithic clasts may be assigned to different types based on their contents of mineralizing elements and textures. These observations are significant because they demonstrate that, at least in parts of the deposit, U-V mineralization did not to any large extent take place in-situ in the host sandstone, but was introduced in a variety of mostly fine-grained, clay-rich pre-existing sediments. The diversity of clasts present indicates that the source sediment was variable in nature and in mineralization type. Based on the observations made, they were likely poorly consolidated sediments that were 'ripped-up' and re-deposited down-channel in the stacked fluvial channel system. 


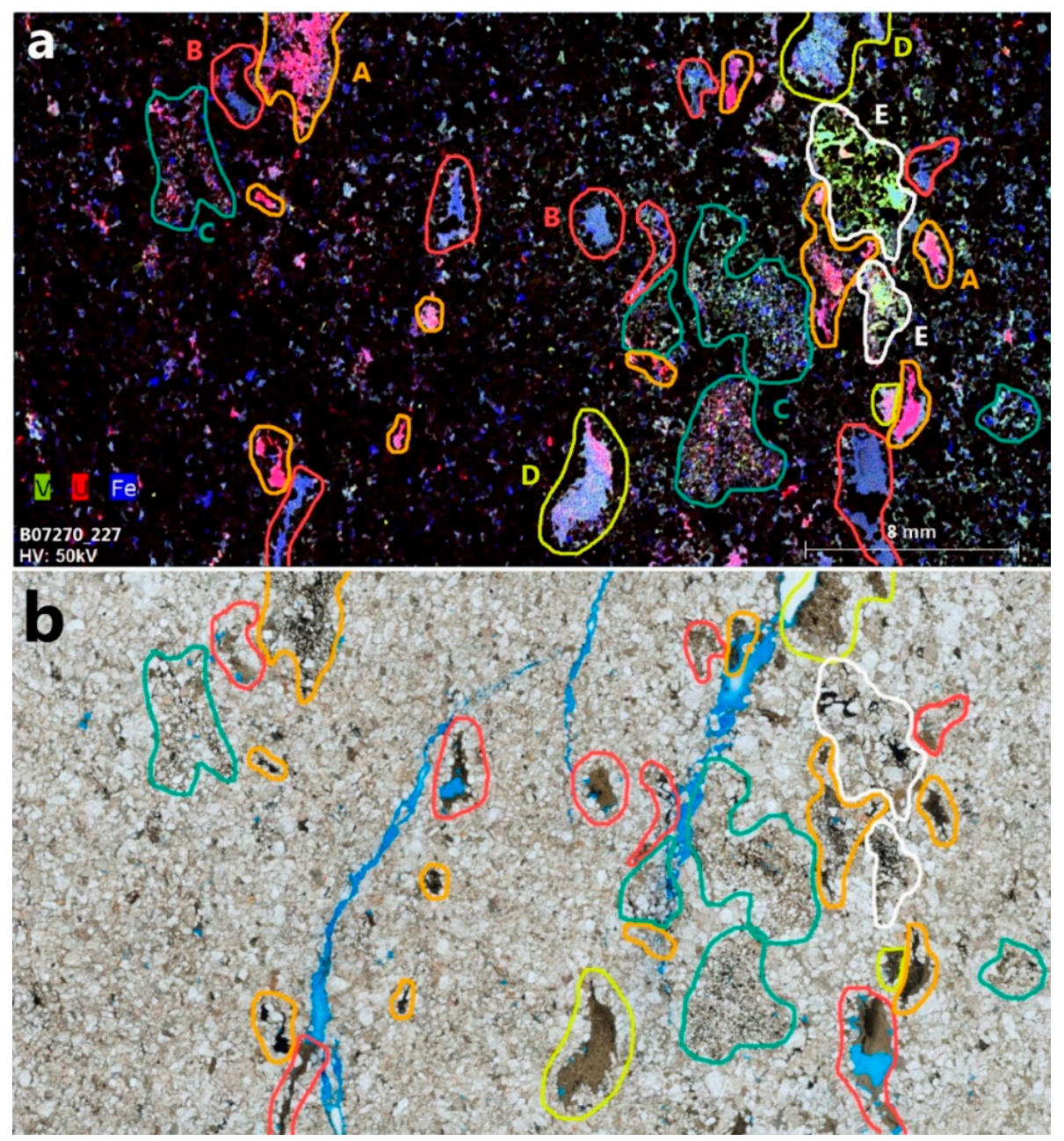

Figure 9. (a) XRF elemental image of vanadium-rich core sample B07270-227m $\left(\mathrm{V}_{2} \mathrm{O}_{5} \quad 0.88 \%\right.$, $\mathrm{U}_{3} \mathrm{O}_{8} \quad 0.07 \%$ ) categorized by element showing the $\mathrm{V}$-U-Fe characteristics of various kinds of lithic rip-up clasts (mudstone, siltstone and clay-rich matrix-supported sandstone) present in the host sandstone. A (orange): uranium-rich sandstone and mudstone, some chemically zoned; B (red): Fe-rich mudstone; $\mathrm{C}$ (green): clay-rich, fine-grained sandstone, weakly mineralized; D (yellow): V-U-Fe enriched siltstone, zoned; E (white): V-clay- and V-oxide-rich sandstone with coarse and fine-grained domains; (b) same thin section but imaged under plain light showing the heterogeneous textures of the lithic clasts. Blue-stained areas are holes in the thin section where soft, clay-rich material has fallen out during preparation of the section.

As discussed above, lithic clasts containing chlorite and biotite may be variably mineralized, which is also observed petrographically, as shown in Figure 10a, where a V-rich lithic clast is in contact with a composite clast containing a U-rich domain. Detail from another V-rich clast shows that microcrystalline pyrite is associated with altered biotite, while uraninite is present as disseminated grains imbedded in V-chlorite (Figure 10b). In some lithic clasts, detrital angular K-feldspar, quartz and dolomite grains, and minor Ti-V-Fe oxides, have been engulfed by pore-filling, V-bearing chlorite, which is overgrown by calcite cement in places. Zones that are strongly calcite-cemented typically comprise angular grains of quartz and K-feldspar, and remnant mineralized domains floating in the calcite cement, implying calcite cementation occurred before compaction (Figure 10c). Some V-chlorite-rich clasts, and the intergranular matrix of other clasts, are variably mineralized and contain aggregates of montroseite (Figure 10d) or other oxyhydroxide V-minerals (doloresite, haggite). Radiation-induced damage of K-feldspar is apparent adjacent to, but not necessarily in 
contact with, U mineralization (Figure 10d), but is absent in calcite-cemented detrital grains lacking clay mineral content.

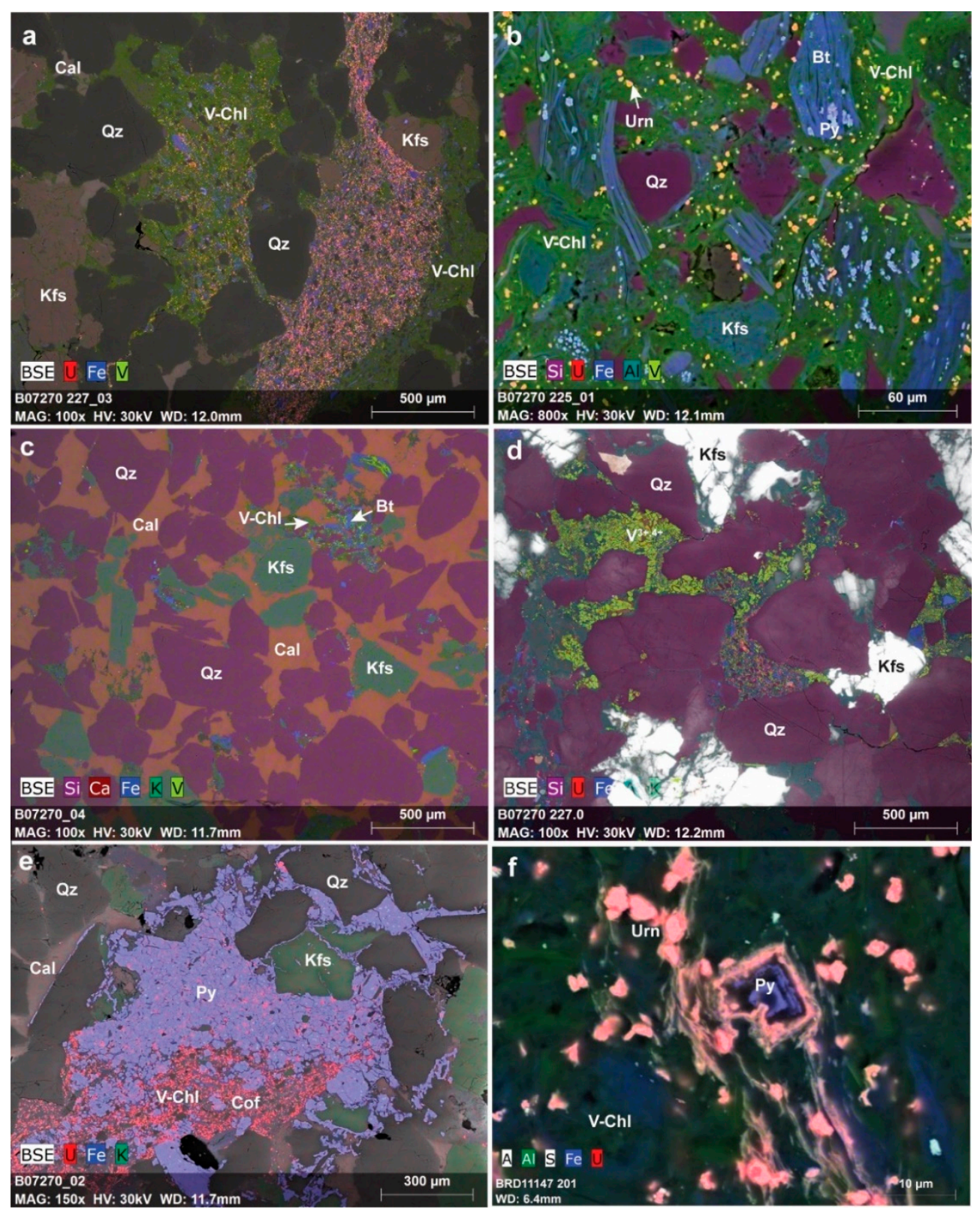

Figure 10. BSE-EDS micrographs illustrating V-minerals textures, (a) detail of compositionally diverse clay-rich lithic clasts showing V-rich and U-rich domains; (b) detail of a V-clay-rich domain of a lithic clast showing V-chlorite/corrensite (green) with imbedded disseminated fine-grained uraninite, pyrite framboids and altered pyritized biotite; (c) calcite-cemented domain in which the pore-space and grain boundaries have been invaded and flooded by calcite prior to compaction; (d) composite SEM/CL image of a V-rich domain showing intergranular matrix composed of V-chlorite and aggregates of bladed montroseite crystals; fractured K-feldspar grains show radiation damage along fractures, yet there is no contact with U-minerals; (e) late pyrite aggregate in a U-mineralized domain; (f) early pyrite skeletal crystallite replaced by uraninite within V-chlorite.

Pyrite may be present in different generations in mineralized samples. Early-formed microcrystalline skeletal pyrite is commonly imbedded in the V-clay-rich matrix, and overgrown and partly replaced by uraninite (Figure 10f). Late-formed pyrite may occur as large 
aggregates occupying pore space and coating grain boundaries. In some instances, pyrite aggregates are associated with strongly U-V-mineralized clay clasts, and are enclosed by calcite cement (Figure 10e).

In some V-rich samples that lack uranium or evidence of previously residing uranium, a different detrital provenance is recognized among the lithic clasts. The clasts are composed of rounded quartz grains and minor K-feldspar without radiation-induced damage bonded by silica cement (Figure 11a,b). Pore spaces and fractures are occupied by V-chlorite and calcite cement. The clasts likely represent recycled silicified sandstone or quartzite sourced from older stratigraphic units. On the other hand, some V-rich samples containing detrital, immature, interlocked K-feldspar and quartz grains show intense radiation-induced damage, but lack any significant uranium content (Figure 11c,d). This is further illustrated in Figure 11e,f which show a K-feldspar grain isolated by calcite cement with cracks and fractures that are filled by pyrite and V-bearing clay minerals (Figure 11f), but uranium minerals are absent. Radiation-induced damage, however, is visible in fractures and along the edges of the grain (Figure 11f), suggesting it is inherited and hints at a former significant uranium content in a grain of granitic provenance.
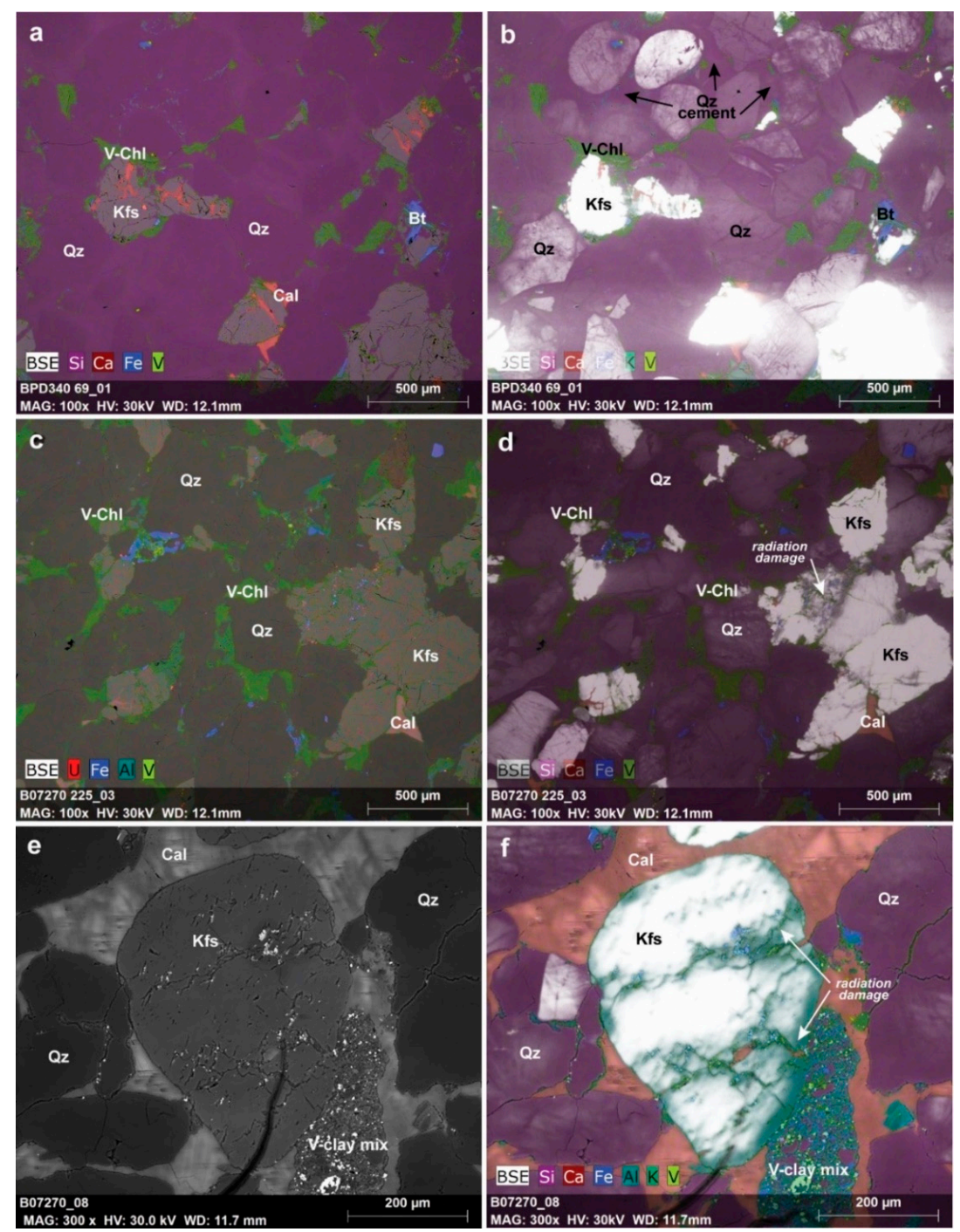

Figure 11. Paired BSE-EDS and CL/SEM micrographs showing different lithic clast types and radiation-induced damage, $(\mathbf{a}, \mathbf{b})$ lithic clasts composed of re-deposited sandstone with inherited quartz cement, pore space composed of V-chlorite; (c,d) immature, angular lithic clasts of granitic origin with pervasive $\mathrm{V}$-chlorite and minor U-minerals associated with radiation-induced damaged K-feldspar; (e,f) calcite-cemented sandstone engulfing radiation-induced damaged K-feldspar. 


\subsection{Geochemistry}

\subsubsection{Geochemical Signature of U-V Mineralization}

The whole-rock major and trace-element geochemistry of the Bigrlyi deposit has been investigated in order to better understand the geochemical signatures related to U-V mineralization and to further test the mineralogical correlations observed in drill core.

Major and trace element variations across U-V-mineralized zones have been explored using the isocon plot method after Grant [32]. Originally, isocon plots were used to characterize metasomatic alteration, showing mass transfer between mineralized and non-mineralized zones, if the host-rock was geochemically identical. The Bigrlyi sandstones are not metasomatically altered, however similar principles can be applied. A non-mineralized sample, of similar grain size and bulk major element contents including $\mathrm{Si}, \mathrm{Al}, \mathrm{K}$ and $\mathrm{Ca}$, has been used as the host-rock reference sample. Ratios of barren versus mineralized samples were calculated, and plotted for a transect across the mineralized zone from 191.3 to $200.3 \mathrm{~m}$ in drill core B07120 from the A4 sub-deposit (Figure 12a-d). The concentrations of Se, $\mathrm{Li}, \mathrm{Ba}, \mathrm{Be}, \mathrm{Mo}, \mathrm{Mg}$ and $\mathrm{Fe}$, in relation to these elements in the non-mineralized sample, show marked enrichments across the mineralized interval, whereas $S$ is strongly depleted.
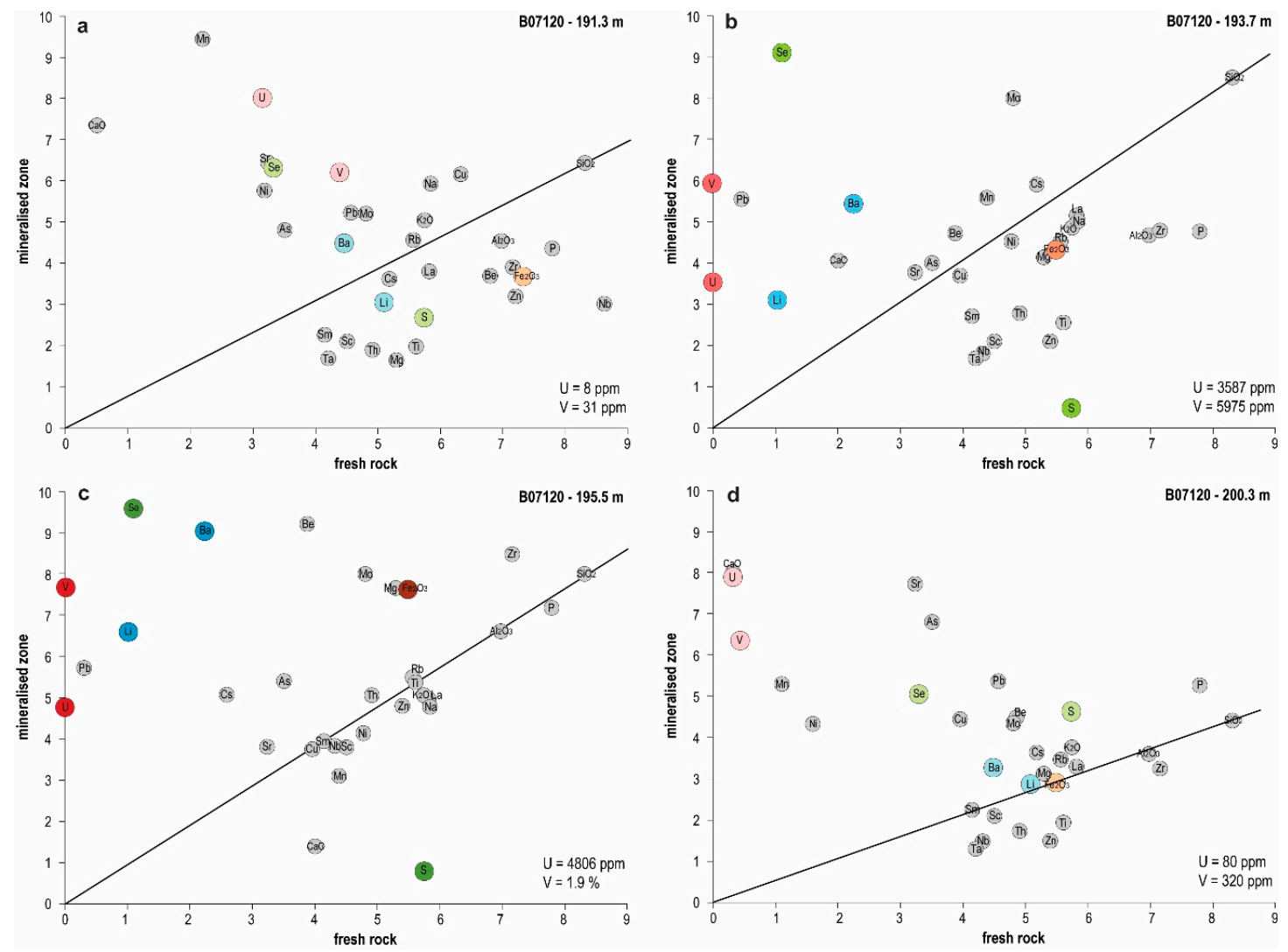

Figure 12. Isocon plots showing element variation across the mineralized zone of drill core B07120, (a) calcite-cemented interval $2 \mathrm{~m}$ above the mineralization shown by CaO-enrichment compared to reference sample; (b) mineralized zone showing enrichment of $\mathrm{Li}$, Ba and Se beside U-V mineralization and depletion of S; (c) mineralized zone with high $\mathrm{V}$ concentration showing enrichment of $\mathrm{Li}, \mathrm{Ba}, \mathrm{Se}$, $\mathrm{Be}$ and $\mathrm{Fe}, \mathrm{Mg}$ and depletion of $\mathrm{S}$; (d) calcite-cemented interval $5 \mathrm{~m}$ below the mineralization showing elevated U-V.

A set of multi-element geochemical data from barren to highly mineralized sandstone, categorized by mineralization type, was used to further explore chemical variance via the Principal Component Analysis (PCA) method. PCA allows complex multivariate data to be displayed in a lower 
dimensional space to simplify and aid interpretation. From inspection of an initial correlation matrix, it was found that certain elements were strongly inter-correlated, reflecting similar geochemical behavior. For the purposes of the analysis, these elements were grouped together as follows: chalcophile-related, $\mathrm{Se}+\mathrm{As}+\mathrm{Mo}+\mathrm{Sb}$; monazite/apatite-related, $\mathrm{La}+\mathrm{Ce}+\mathrm{Y}(\mathrm{REE})+\mathrm{P}$; heavy mineral-related, $\mathrm{Zr}+\mathrm{Nb}+\mathrm{Ti}$ $+\mathrm{Th}+\mathrm{Sn}$; mafic/ultramafic-related, $\mathrm{Cr}+\mathrm{Ni}+\mathrm{Co}+\mathrm{Cu}$; and biotite/chlorite/corrensite-related, $\mathrm{Fe}+\mathrm{Mg}$. The data were log-transformed, and based on the correlation matrix, the principle components were extracted using the Fast MCD algorithm. Table 1 provides a summary of key element abundances and ratios for each mineralization category. Further data are provided in Supplementary Data Table S1.

Table 1. Geometric mean * abundances of key elements and ratios by mineralization category.

\begin{tabular}{|c|c|c|c|c|c|}
\hline $\begin{array}{c}\text { Mineralization } \\
\text { Type }\end{array}$ & $\begin{array}{c}\text { Barren or Weakly } \\
\text { Mineralized } \\
n=25\end{array}$ & $\begin{array}{l}\text { Vanadium } \\
\text { Halo } \\
n=23\end{array}$ & $\begin{array}{c}\text { Strongly } \\
\text { V-Mineralized } \\
\mathrm{n}=28\end{array}$ & $\begin{array}{c}\text { U and } \\
\text { V-Mineralized } \\
n=19\end{array}$ & $\begin{array}{c}\text { Strongly } \\
\text { U-Mineralized } \\
\mathbf{n}=\mathbf{1 1}\end{array}$ \\
\hline V ppm & 20 & 188 & 7716 & 2209 & 1924 \\
\hline U ppm & 5 & 18 & 398 & 2613 & 18,648 \\
\hline Se ppm & 1.5 & 2.0 & 18.9 & 9.8 & 122.1 \\
\hline S ppm & 974 & 294 & 491 & 307 & 541 \\
\hline $\mathrm{Se} / \mathrm{S}$ & 0.002 & 0.007 & 0.039 & 0.032 & 0.226 \\
\hline $\mathrm{Pb}$ ppm & 17 & 20 & 48 & 142 & 960 \\
\hline Li ppm & 7.7 & 11.7 & 28.8 & 27.3 & 40.7 \\
\hline Be ppm & 0.7 & 1.0 & 1.5 & 2.2 & 3.1 \\
\hline Ba ppm & 461 & 473 & 494 & 727 & 1314 \\
\hline K \% & 2.33 & 2.32 & 2.23 & 2.19 & 2.35 \\
\hline $\mathrm{Al} \%$ & 3.04 & 3.22 & 3.48 & 3.48 & 3.43 \\
\hline $\mathrm{K} / \mathrm{Al}$ & 0.77 & 0.72 & 0.64 & 0.63 & 0.69 \\
\hline $\mathrm{Fe}+\mathrm{Mg} \%$ & 1.34 & 1.97 & 2.56 & 2.04 & 2.47 \\
\hline Cr ppm & 29 & 46 & 15 & 28 & 61 \\
\hline $\mathrm{Ca} \%$ & 2.27 & 3.12 & 0.47 & 0.50 & 1.09 \\
\hline
\end{tabular}

* Average of log-transformed data.

The PCA analysis shows that the elements $\mathrm{Ca}$, Sr and Mn behave similarly and have high variance vectors that clearly relate to the variable abundance of calcite cement in the sandstones (Figure 13). Aluminum shows the opposite behavior due to the lower contents of clays and K-feldspar in calcite-cemented sandstone. The $\mathrm{U}$ vector is accompanied by a similar vector for $\mathrm{Pb}$, reflecting radiogenic lead production from $\mathrm{U}$ decay. Other U-associated vectors include the chalcophile elements $\mathrm{Se}+$ $\mathrm{As}+\mathrm{Mo}+\mathrm{Sb}$. The Ba and Be vectors also show a strong relationship with $\mathrm{U}$ (see also Table 1). Of interest is the decoupling seen between the $\mathrm{Se}+\mathrm{As}+\mathrm{Mo}+\mathrm{Sb}$ and $\mathrm{S}$ vectors, with $\mathrm{Se} / \mathrm{S}$ ratios, for example, showing an increase of two orders of magnitude in strongly U-mineralized samples compared to barren sandstone (Table 1). The $\mathrm{V}$ vector is accompanied by a similar vector for $\mathrm{Li}$, which is presumably a result of the preferential concentration of $\mathrm{Li}$ in the phyllosilicate minerals that host most of the V. Strongly V-mineralized samples are influenced by the $\mathrm{Fe}+\mathrm{Mg}$ vector, which reflects the importance of chlorite and related minerals as hosts for $\mathrm{V}$. The vector for $\mathrm{K}$ is anticorrelated with $\mathrm{V}$, which likely relates to the enhanced alteration and chloritization of detrital biotite and lower $\mathrm{K}$-feldspar-to-clay-mineral ratios in V-mineralized samples; this is also seen in the lower K/Al ratios of mineralized samples (Table 1). 


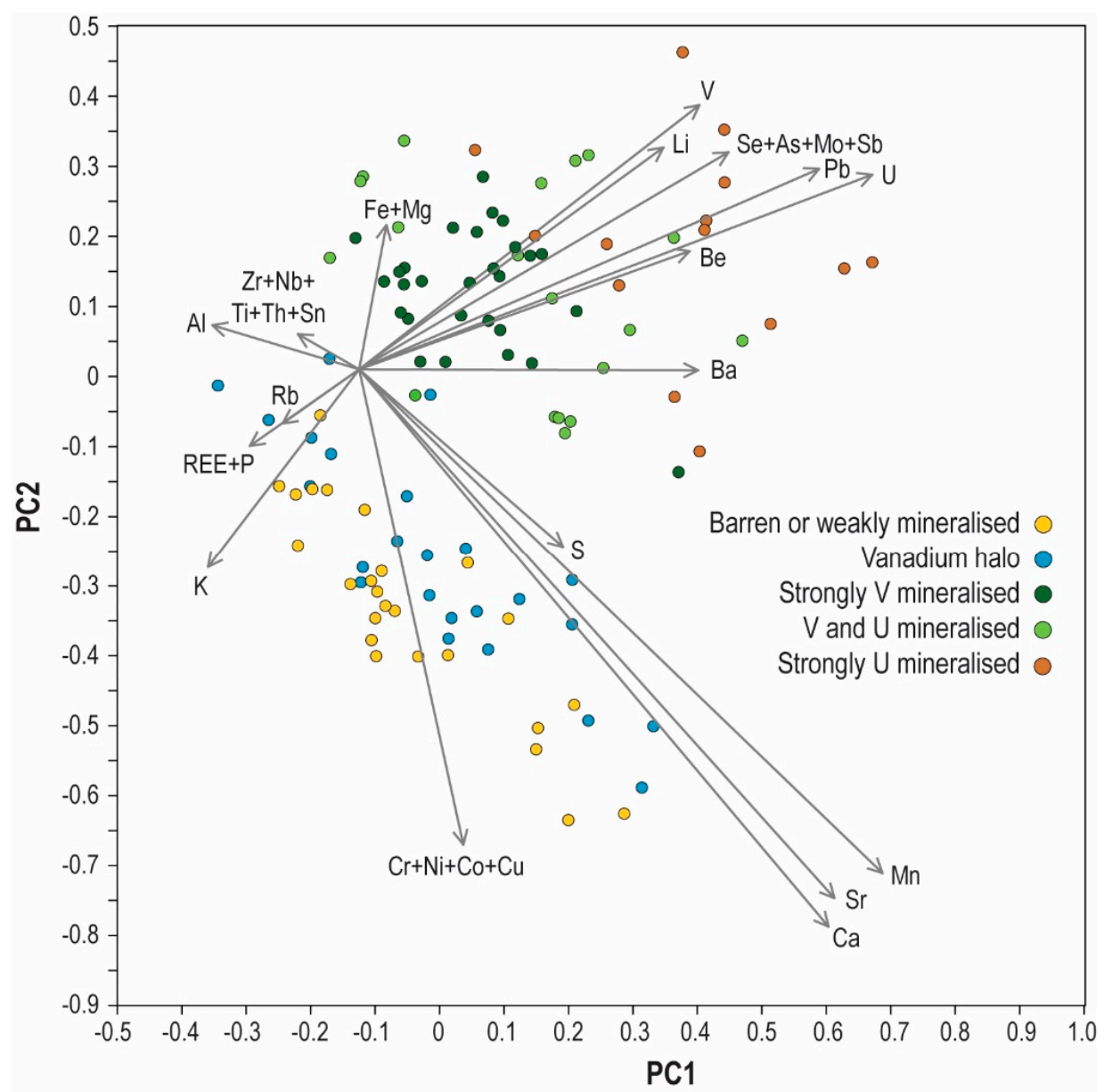

Figure 13. Principal Component Analysis vector plot for the Bigrlyi multi-element geochemical dataset categorized by mineralization type (see text for further details). The length of the PCA vectors is proportional to the variability of the principal components, and the direction of the vector and its proximity to the sample points indicates how heavily the sample position is influenced by that variable.

\subsubsection{Organic Carbon}

In view of the importance of organic carbon as a reductant in tabular U-V sandstone-hosted deposits of the Colorado Plateau, and its apparent rarity in petrographic studies of the Bigrlyi deposit, the Bigrlyi geochemical dataset was interrogated for organic carbon analyses from samples of barren and mineralized sandstone and siltstone/shale (Table 2). The results confirm observations, showing that only low levels of organic carbon are present, with a maximum value of $0.46 \% \mathrm{C}$ recorded from a weakly mineralized shale. Although the shales have slightly higher organic carbon contents than the sandstones, no association between the content of carbonaceous matter and mineralization is evident (Table 2).

Table 2. Geometric mean * abundances and range of organic carbon contents in Bigrlyi samples.

\begin{tabular}{cccc}
\hline Rock Type & Sandstone, $\mathbf{n}=\mathbf{2 0 4}$ & Siltstone/Shale, $\mathbf{n}=\mathbf{3 6}$ & Mineralized, $\mathbf{> 0 . 1 \%} \mathbf{V}, \mathbf{n}=\mathbf{7 2}$ ** \\
\hline C organic $\%$ & 0.015 & 0.032 & 0.017 \\
(Range \%) & $0.01-0.10$ & $0.01-0.46$ & $0.01-0.13$ \\
C inorganic $\%$ & 0.56 & 0.61 & 0.30 \\
V ppm avg. & 459 & 1214 & 5230 \\
Fe \% avg. & 0.83 & 1.95 & 1.22 \\
\hline
\end{tabular}

${ }^{*}$ Average of log-transformed data; ${ }^{* *}$ Sub-set of the $\mathrm{n}=204$ dataset. 


\subsubsection{Pb Isotopes}

The $\mathrm{Pb}$ isotopes ${ }^{206} \mathrm{~Pb}$ and ${ }^{207} \mathrm{~Pb}$ are the ultimate radiogenic daughter products of radioactive decay in the ${ }^{238} U$ and ${ }^{235} U$ decay chains, respectively. In uranium deposits such as Bigrlyi that are old enough to allow sufficient ingrowth of radiogenic $\mathrm{Pb}$, there is a strong correlation between the abundances of $\mathrm{Pb}$ and $\mathrm{U}$ (Figure 13 and Table 1 ). Because $\mathrm{U}$ and $\mathrm{Pb}$ have different chemical behaviors, they may be affected to different extents by post-depositional processes such as oxidative leaching. The abundance of radiogenic $\mathrm{Pb}$ relative to $\mathrm{U}$ may therefore be used to provide an insight into the differential mobility of these elements over time since deposit formation. If the mineralized system remained closed and undisturbed since formation, i.e., $\mathrm{U}$ and $\mathrm{Pb}$ remained immobile, then the amount of radiogenic $\mathrm{Pb}$ present will be proportional to the uranium content of the rock and the time elapsed since the mineralization event; in such cases, the $\mathrm{U}-\mathrm{Pb}$ isotopic system will exhibit concordant behavior. If open system processes disturbed the ore body and mobilized $\mathrm{U}$ or $\mathrm{Pb}$ post-mineralization, then the $\mathrm{U}-\mathrm{Pb}$ isotopic system will exhibit discordant behavior. Measurements of the Pb-isotopic composition of a sample can be used to quantify the mobility (gain or loss) of $\mathrm{U}$ relative to $\mathrm{Pb}$. As discussed, in the Bigrlyi deposit there is petrographic evidence for post-mineralization $U$ mobility, which is expected to have disturbed the $\mathrm{U}-\mathrm{Pb}$ isotopic system. To explore the nature of these post-mineralization processes, a whole-rock $\mathrm{Pb}$-isotope dataset, that covers the range of $\mathrm{U}-\mathrm{V}$ mineralization types, has been compiled (Supplementary Data Table S2). Standard equations were used to calculate the abundance of radiogenic $\mathrm{Pb}$ and a common $\mathrm{Pb}$ isotope correction was applied to calculate the concentrations of the individual radiogenic isotopes $\left({ }^{206} \mathrm{~Pb}^{*},{ }^{207} \mathrm{~Pb}^{*}\right.$ and $\left.{ }^{208} \mathrm{~Pb}^{*}\right)$. Other key isotope ratios were then determined. For the Bigrlyi deposit, Th is of negligible abundance relative to $\mathrm{U}$, and therefore ${ }^{208} \mathrm{~Pb}^{*}$, the daughter of the Th-decay chain, is not a significant component of this system.

The whole-rock $\mathrm{U}-\mathrm{Pb}$ results show that the majority $(70 \%)$ of the data points are significantly discordant, and plot above and below the concordia curve in ${ }^{207} \mathrm{~Pb}^{*} /{ }^{206} \mathrm{~Pb}^{*}$ versus ${ }^{238} \mathrm{U} /{ }^{206} \mathrm{~Pb}^{*}$ space; the scatter of data points confirms that parts of the Bigrlyi deposit have experienced time-integrated gains or losses of $\mathrm{U}$ and/or $\mathrm{Pb}$ from the system (Table S2). Significantly, however, 11 of the data points plot within a few percent of the concordia curve, do not show evidence for significant U gain or loss, and using the ${ }^{238} \mathrm{U}-{ }^{206} \mathrm{~Pb}$ chronometer give a geologically reasonable, broad timing of mineralization in the range 282 to $335 \mathrm{Ma}$ (i.e., mid-to-late Carboniferous) at the $2 \sigma$ level $\left({ }^{238} \mathrm{U} /{ }^{206} \mathrm{~Pb}^{*} 20.5 \pm 1.8\right)$. This provides confidence in the quality and internal consistency of the dataset.

The amount of radiogenic $\mathrm{Pb}$ present in a sample was used to calculate the expected uranium content of that sample, assuming $300 \mathrm{Ma}$ of evolution of the U-Pb decay chains and closed-system behavior (Supplementary Materials Table S2). Any gain or loss of U relative to $\mathrm{Pb}$ in a sample can be expressed as a percent deviation of the present-day uranium content from the expected uranium concentration. As determined from reproducibility of the internal standard, the precision of the percentage deviation is $\pm 8 \%$ absolute at the $2 \sigma$ level, so that any deviation above this level is expected to be of significance. As a simple rule of thumb, the ratio of $U$ to total radiogenic $\mathrm{Pb}\left(\mathrm{U} / \mathrm{Pb} b^{*}\right)$, as listed in Table S2, is indicative of closed system behavior when that value is near 20, and deviates to lower or higher values where there has been mobility of radiogenic elements (i.e., open system behavior).

\section{Discussion}

\subsection{Pb-Isotope Constraints on U-Mobility and Open System Behavior}

Petrographic observations showing radiation-induced damage of detrital minerals in the absence of associated uranium provide evidence for the mobility of uranium, and hence for open system behavior for radiogenic elements over time. Since $\mathrm{V}$ is likely to be largely immobile as a component of aluminosilicate minerals, the mobilization of $U$ relative to $V$ and its re-precipitation could be a significant process in upgrading U-rich parts of the deposit following sedimentary deposition. This view is supported and reinforced by the $\mathrm{Pb}$-isotope results, which provide evidence for time-integrated $\mathrm{U}$ mobility across the deposit. The deviation between measured $U$, and $U$ calculated on the basis of 
radiogenic $\mathrm{Pb}$ content, has been explored as a function of $\mathrm{V} / \mathrm{U}$ ratio in Figure 14, with the data points categorized by mineralization type as per Table 1 . The following interpretations can be made:

- About $30 \%$ of the Pb-isotope dataset, including many of the strongly U-mineralized samples, show closed system behaviors within error; presumably these mineralization sites were protected from U- and/or Pb-mobility by impermeable barriers soon after formation, preventing the infiltration of oxidized fluids post-mineralization;

- About $45 \%$ of the Pb-isotope dataset shows evidence for time-integrated U-loss relative to $\mathrm{Pb}$ (i.e., these samples have radiogenic $\mathrm{Pb}$ concentrations that are unsupported by current $\mathrm{U}$ levels). This category mainly comprises samples from the vanadium halo and from strongly V-mineralized zones;

- The remaining $25 \%$ of the $\mathrm{Pb}$-isotope dataset show evidence for time-integrated U-gain relative to $\mathrm{Pb}$ (i.e., these samples have $\mathrm{U}$ levels that are unsupported by their current radiogenic $\mathrm{Pb}$ contents).

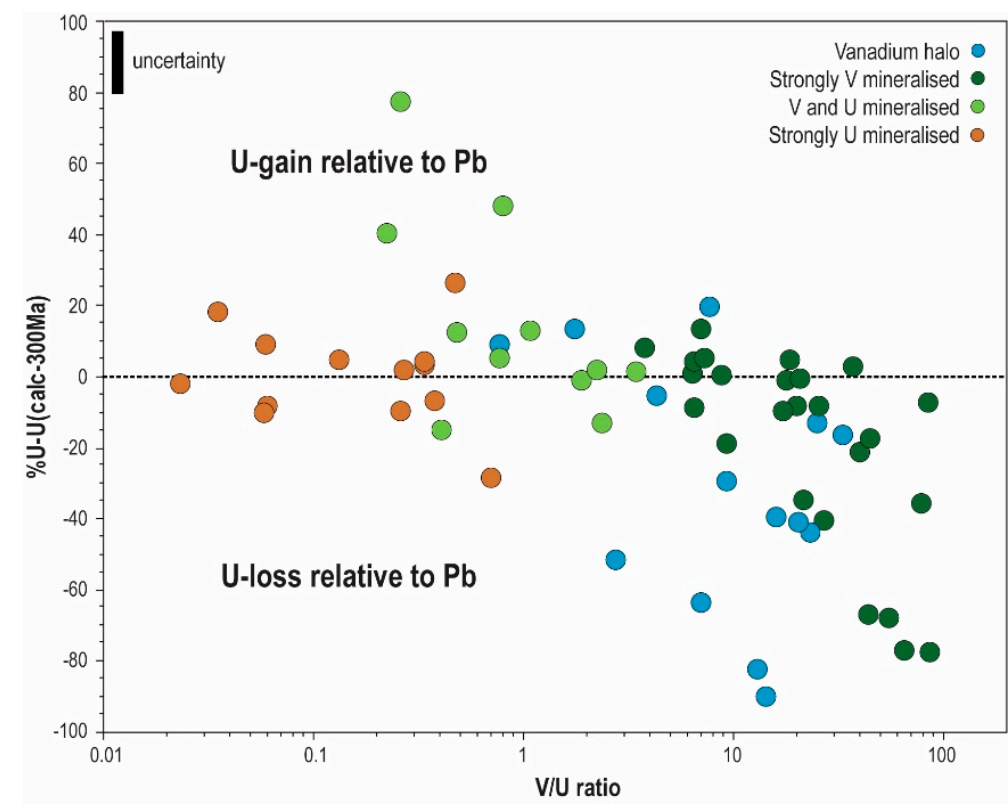

Figure 14. Percent deviation of uranium concentration from that expected for $300 \mathrm{Ma}$ of closed system uranium decay, based on the concentration of present-day radiogenic $\mathrm{Pb}$ plotted versus sample $\mathrm{V} / \mathrm{U}$ ratio. Data points are categorized by mineralization type as in Table 1 . Samples showing time-integrated $\mathrm{U}$-loss relative to $\mathrm{Pb}$ (i.e., samples with radiogenic $\mathrm{Pb}$ unsupported by current $\mathrm{U}$ levels) plot below the $0 \%$ line, and mainly comprise those from the vanadium halo and from strongly V-mineralized zones.

In Table 3, some examples of downhole variation are used to illustrate the scale of radiogenic element mobility. The data show that variations between closed system and open system behavior may fluctuate downhole over scales, from $\sim 0.4 \mathrm{~m}$ up to several meters' width, with U-loss relative to $\mathrm{Pb}$ being most common in intervals of high $\mathrm{V} / \mathrm{U}$. Note also that the lithic-clast-rich, $\mathrm{V}>\mathrm{U}$-mineralized sample B07270 — 227 m, previously described (Figure 9), shows strictly closed-system behavior, confirming this sample as an example of unmodified mineralized sandstone. 
Table 3. Downhole variation of $\mathrm{U}, \mathrm{V}, \mathrm{Pb}$ and calculated $\mathrm{U}$ based on radiogenic $\mathrm{Pb}$.

\begin{tabular}{|c|c|c|c|c|c|c|c|c|c|}
\hline $\begin{array}{l}\text { Drill } \\
\text { Hole\# }\end{array}$ & $\begin{array}{l}\text { Depth } \\
\text { (m) }\end{array}$ & $\mathrm{U}(\mathrm{ppm})$ & $\mathrm{V}(\mathrm{ppm})$ & $\mathrm{Pb}(\mathrm{ppm})$ & $\mathrm{V} / \mathrm{U}$ & $\begin{array}{c}\mathrm{Pb} * \\
(\mathrm{ppm})\end{array}$ & $\mathrm{U} / \mathbf{P b}$ * & $\begin{array}{c}\mathrm{U}(\text { calc) } 300 \mathrm{Ma} \\
(\mathrm{ppm})\end{array}$ & $\%$ U-U(calc) ** \\
\hline BPD321 & 137.1 & 774 & 15,600 & 62.0 & 20.2 & 42.7 & 18.1 & 842 & -8 \\
\hline BPD321 & 137.95 & 895 & 6290 & 60.9 & 7.0 & 40.1 & 22.3 & 790 & +13 \\
\hline BPD321 & 140.1 & 105 & 8250 & 29.6 & 78.6 & 8.5 & 12.4 & 163 & -36 \\
\hline BPD321 & 141.6 & 651 & 12,000 & 47.4 & 18.4 & 31.4 & 20.7 & 622 & +5 \\
\hline BPD321 & 144.0 & 205 & 5190 & 27.4 & 25.3 & 11.2 & 18.3 & 223 & -8 \\
\hline BPD321 & 144.5 & 239 & 4140 & 33 & 17.3 & 13.2 & 18.1 & 264 & -10 \\
\hline BPD321 & 147.0 & 2460 & 5870 & 159 & 2.4 & 140.1 & 17.6 & 2827 & -13 \\
\hline BPD321 & 148.6 & 206 & 11,300 & 49.8 & 54.9 & 31.8 & 6.5 & 636 & -68 \\
\hline BPD321 & 149.2 & 152 & 9920 & 52.7 & 65.3 & 33.0 & 4.6 & 655 & -77 \\
\hline B07270 & 225.0 & 678 & 4910 & 53.9 & 7.24 & 32.9 & 20.6 & 644 & +5 \\
\hline B07270 & 226.4 & 133 & 4890 & 27.9 & 36.8 & 6.6 & 20.2 & 129 & +3 \\
\hline B07270 & 227.0 & 560 & 4930 & 47.6 & 8.8 & 27.9 & 20.0 & 558 & 0 \\
\hline B07270 & 227.6 & 94 & 4180 & 25.3 & 44.5 & 6.0 & 15.6 & 113 & -17 \\
\hline B07270 & 228.9 & 2610 & 8900 & 145 & 3.4 & 128.3 & 20.3 & 2572 & +2 \\
\hline B07270 & 229.3 & 1250 & 7940 & 86.1 & 6.4 & 62.2 & 20.1 & 1238 & +1 \\
\hline В07270 & 229.7 & 393 & 691 & 35.1 & 1.8 & 17.6 & 22.4 & 347 & +13 \\
\hline
\end{tabular}

${ }^{*}=$ Radiogenic $\mathrm{Pb} .{ }^{* *}$ Closed-system behavior $0 \pm 8 \%$; U-loss $<-8 \%$; U-gain $>+8 \%$.

The $\mathrm{Pb}$-isotope results suggest that over time $\mathrm{U}$ has been mobilized from the vanadium halo and from strongly V-mineralized zones and redistributed to other parts of the deposit, resulting in zones of later U-enrichment. These mobility pathways were presumably open from early in the history of the Bigrlyi deposit, although the earliest events, occurring immediately post-deposition, may not necessarily be apparent due to the time required for the ingrowth of sufficient radiogenic $\mathrm{Pb}$ to be detectable. The timing and history of $\mathrm{U}-\mathrm{Pb}$ mobility is not known, but a number of events in the post-depositional period are considered likely in response to tectonic movements or climatic/hydrological changes. Open system processes do not appear to have significantly affected the Bigrlyi deposit within the last $1 \mathrm{Ma}$ or so, since the U-decay chains in unoxidized, sub-surface parts of the Bigrlyi deposit are in secular equilibrium within error [33], and the ratios of ${ }^{238} \mathrm{U}$ to short-lived daughter radionuclides, including ${ }^{210} \mathrm{~Pb}$, have not been disturbed in recent times.

\subsection{Nature and Timing of Bigrlyi U-V Mineralization}

In this study, an integrated sedimentological, mineralogical and geochemical investigation of the distribution of U-V mineralization in the Bigrlyi deposit has been presented. A summary of key observations and interpretations is outlined below.

Sedimentologically, U-V mineralization is concentrated in the basal parts of stacked fluvial channels within the locally reduced facies of an immature, arkosic sandstone (grey sandstone). Uranium-rich and/or V-rich mineralization is mainly concentrated near redox boundaries at the top and base of the host grey sandstone, and a broad halo of lower grade $\mathrm{V}$ mineralization extends through the grey sandstone unit. Minor remnant $\mathrm{U}$ mineralization and broader zones of V-enrichment occur in the underlying and overlying oxidized, hematitic sandstone units. Along the strike there are notable differences in the bulk V:U ratios of the various Bigrlyi sub-deposits, with the A-7/9 sub-deposit being V-rich and U-poor. Within sub-deposit variation of V:U ratios is partly the result of the remobilization of $\mathrm{U}$, as $\mathrm{Pb}$-isotope data and petrographic evidence show. Pb-isotope studies and unsupported radiation-damage-related features in detrital K-feldspar show that fluid pathways did exist within ore zones, allowing access for oxidized fluids and consequent uranium mobilization. Over time, open system element mobility affected some areas of the deposit more than others, including the V-halo and V-rich zones, which show U-loss relative to $\mathrm{Pb}$, with the mobilized $\mathrm{U}$ being re-concentrated in other zones.

Mineralogically, U-V mineralization is strongly associated with phyllosilicate minerals in lithic rip-up clasts and in the clay-rich matrix of the host reduced sandstone. The clay-rich lithic clasts are comprised of mostly fine-grained, partly lithified sediments (mudstone, siltstone and fine sandstone) 
that are texturally and chemically heterogeneous. Some lithic clasts are rich in V, some are rich in $\mathrm{U}$, and some may be zoned with U- and V-rich domains; other clasts are unmineralized and contain Fe-rich phyllosilicates and pyrite. The lithic rip-up clasts were likely derived from a diverse range of heterogeneously mineralized, reduced, mainly fine-grained sediments, which were originally deposited up-channel of their present depositional site. Fluvial channel stacking caused by high-energy events was a result of erosion and scouring of older channels and overbank deposits, and the downstream redeposition of the eroded materials.

The U-V mineralization was in place prior to the precipitation of early diagenetic, groundwater-related calcite cements. The lack of porosity caused by the pore-occluding calcite cement prevented the later infiltration of fluids and oxidative mobilization in large parts of the deposit.

Vanadium occurs dominantly as a $\mathrm{V}^{(\mathrm{III})}$ solid-solution component of Fe-bearing phyllosilicates (roscoelite/illite, chlorite/corrensite and altered biotite), which are present as constituents of lithic rip-up clasts, the intergranular matrix, or gradational zones between the two. The Fe and V-bearing phyllosilicates are compositionally variable and heterogeneously distributed, while the weakly mineralized zones may contain an abundance of Fe-bearing-only phyllosilicates. Vanadium-oxyhydroxide minerals such as montroseite and haggite are less important hosts for V. Montroseite typically occurs as a replacement phase of degraded detrital biotite, or forms aggregates of bladed crystals within the clay-rich matrix or lithic clasts. Detrital Fe-Ti minerals contain variable amounts of $\mathrm{V}$ due to alteration and partial replacement of Fe by $\mathrm{V}$, but the timing of the alteration process is not known.

Uranium in the unoxidized Bigrlyi sub-deposits is present as coffinite and uraninite, with the former dominant. Uraninite commonly occurs as fine-grained disseminations and globular aggregates in association with phyllosilicates, including degraded detrital biotite, and is texturally an early-formed phase. Coffinite is generally a later phase present as massive aggregates replacing uraninite, as encrustations and overgrowths on grain boundaries of detrital quartz, and as fracture-fillings in K-feldspar; the presence of galena inclusions suggests it was recrystallized in later events, releasing and re-precipitating contained radiogenic $\mathrm{Pb}$. Where uranium mineralization is present, pyrite is typically less abundant than in unmineralized zones.

Geochemically, U-V mineralization is characterized by the enrichment of trace Li accompanied by elevated $\mathrm{Fe}+\mathrm{Mg}$, relating to the abundance of phyllosilicates; it is possible that the association of Li with mineralizing elements is a source-related feature, reflecting a common provenance of detrital phyllosilicates. Potassium concentrations and $\mathrm{K} / \mathrm{Al}$ ratios are lower in the mineralized zone, likely due to the higher abundance of phyllosilicates relative to K-feldspar. In strongly U-mineralized zones chalcophile elements, such as Se, are significantly enriched relative to sulfur, resulting in characteristically elevated Se/S ratios; the effect is present but less pronounced in V $>$ U-mineralized zones. Uranium mineralization is also correlated with elevated Be and $\mathrm{Ba}$, but it is unclear whether this association is related to a common source-region provenance or to preferential concentration during the mineralization process. Lastly, $\mathrm{V}$ mineralization is poorly correlated and decoupled from the mafic/ultramafic elements, suggesting a mafic igneous source for $\mathrm{V}$ is less likely than a black shale or hydrothermal source.

\subsection{Implications for Mineralization Models}

As petrographic observations suggest, vanadium was largely introduced, as detrital clasts or disseminated $\mathrm{V}^{\text {(III) }}$-bearing phyllosilicates (roscoelite, chlorite, biotite), into the Bigrlyi host sandstone as detritus eroded from sites located up-channel and in the exposed basement of the hinterland. It is probable that localized diagenetic decomposition of the $\mathrm{V}$-bearing minerals resulted in the formation of vanadium oxyhydroxides, such as montroseite ( $\mathrm{V}^{(\mathrm{III})}$-bearing), haggite $\left(\mathrm{V}^{(\mathrm{III})}, \mathrm{V}^{(\mathrm{IV})}\right.$-bearing) and doloresite $\left(\mathrm{V}^{(\mathrm{IV})}\right.$-bearing), prior to calcite cementation and under mostly reducing conditions. Therefore, $\mathrm{V}$ mineralization at Bigrlyi did not take place in-situ in the host sandstone by processes involving the transport of soluble V in groundwaters and its precipitation at the site of deposition. 
Further, as early-formed U-minerals are intimately associated with Fe-V-phyllosilicates, such as those occurring in heterogenous U-enriched lithic clasts, it is proposed that at least a portion of Bigrlyi $\mathrm{U}$ was also originally introduced into the host sandstone as detrital components. Original up-channel sites associated with mineralization most likely comprised reduced, clay-rich sediment intervals; at the site of deposition, prolonged reducing conditions preserved the mineralized zones.

While parts of the deposit remained under reducing conditions due to the lack of porosity and permeability (chemical compaction by calcite-cemented beds, and mechanical compaction), at least some zones were open to fluid exchange. Evidence provided from both petrography and $\mathrm{Pb}$-isotope studies indicate that fluid access pathways existed over long time periods within the V-halo and within other V-rich mineralized domains of the Bigrlyi deposit. Such pathways permitted, over time, the variable access of oxidized fluids into the grey sandstone host, resulting in mobilization and the loss of $\mathrm{U}$ from the $\mathrm{V}$-bearing domains, and its re-concentration elsewhere in the deposit, while $\mathrm{V}$ remained essentially fixed as an immobile component of aluminosilicate minerals. Patches of V mineralization, associated with weak remnant $U$ mineralization located in oxidized sandstone stratigraphically above and below the main host, hint at the more widespread mobilization of $U$ outside ore zones.

The presence of earlier sites of U-V mineralization located in up-channel sediments echo the multiple migration-accretion hypothesis of Gruner [34] and the pre-concentration model of Finch and Davis [35]. What kind of processes could be responsible for mineralization in the earlier deposited sediments? Gruner proposed that the "Concentration of large deposits could proceed by several stages of oxidation-solution-migration-accretion, a kind of recycling action" involving multiple cycles of oxidative dissolution of $\mathrm{U}$ and $\mathrm{V}$ and the re-precipitation of these elements by interaction with carbonaceous matter or hydrogen sulfide. Finch and Davis [35] suggested that "uranium could have been pre-concentrated during deposition of overbank boggy mudstone", again emphasizing a role for carbonaceous matter as a reductant. Neither of these models include a role for detrital materials, and in the case of Bigrlyi the low organic carbon content would rule out a significant role for carbonaceous matter as a reductant. Yet at Bigrlyi, vanadium and some uranium were pre-concentrated in detrital components. A hybrid model involving an interplay between solution-precipitation processes, detrital transport, pre-concentration and post-depositional U remobilization may be the most appropriate model to accommodate all the features of the Bigrlyi deposit.

The ultimate source of Bigrlyi vanadium is not known, but a black shale source or a hydrothermal source (such as the roscoelite-related alteration identified in some alkaline magmatic systems, e.g., [36]) in the hinterland are possible. Original detrital components, as well as oxidatively leached $V^{(V)}$ from such a source, could have both been contributors to the V source inventory. Uranium was most likely leached from uraniferous granitoids and pegmatites in the basement Arunta terrain, and transported as stable $\mathrm{U}^{(\mathrm{VI})}$ carbonate complexes. In fact, polycrystalline quartz-K-feldspar clasts showing radiation-induced damage features, but lacking uranium content are found in the host sandstone, and likely represent uranium-leached detritus from the granitic source region.

The primary reductants (and adsorbents) were likely to be Fe(II)-bearing clay minerals and pyrite; $\mathrm{Fe}(\mathrm{II})$ is known to be a thermodynamically favored abiotic reducer of $\mathrm{U}^{(\mathrm{VI})}$ [37], and pyrite is an efficient scavenger of soluble $\mathrm{U}^{(\mathrm{VI})}$ [38]. There may also be a role for $\mathrm{V}^{(\mathrm{III})}$-bearing minerals as reductants. The key element selenium is mobile as soluble selenite anions in oxidized waters, and is precipitated under reducing conditions as metal selenides. In roll-front deposits, Se is closely associated with the U orebody due to these elements having similar redox behaviors [39]. In Bigrlyi, elevated Se/S ratios in U-mineralized zones may be the result of pyrite replacement, $\mathrm{S}$ mobilization and the liberation of pyrite-derived Se, followed by selenide and U mineral co-precipitation.

The proposed mineralization model for Bigrlyi is envisaged as a solution-precipitation process combined with the transport of U-V-mineralized detritus, as follows. The erosion of a hinterland vanadium source results in the introduction of Fe-V-bearing detrital phyllosilicate-rich materials into the fluvial system. Vanadium-bearing minerals located in sites above a fluctuating water table may be oxidatively mobilized and locally re-precipitated by reaction with Fe-rich detrital minerals, in a process 
of 'vanadization'. Oxidative leaching of uraniferous granites and pegmatites in the hinterland provides the main source of soluble $U$, which is reduced and precipitated the same depositional sites as host Fe-V-bearing phyllosilicates. These initial sites (immature fluvial channels) were eroded and scoured out in flood events, and a mix of semi-lithified mineralized sediments were re-deposited downstream. Mineralized detrital materials are eventually concentrated in a reduced aquifer downstream in the fluvial channel system. Uranium is mobilized and reprecipitated as coffinite in various later events that cause $U$ to be redistributed from V-rich domains and from partly oxidized parts of the stratigraphy. The aquifer is isolated, and mineralization is protected by chemical barriers and mechanical compaction. The deposit is affected by tectonism associated with basin shortening and inversion, and the host stratigraphy is exhumed and tilted vertically on the northern margin of the basin, a possible driver for $\mathrm{U}$ redistribution early in the deposit history.

The preservation and mineralization potential in the Bigrlyi deposit is controlled by the deposition of detrital phyllosilicates as clasts or matrix clays, calcite cementation driven by evaporation, and fluvial channel architecture [27]. An exploration implication of the mineralization model is the recognition that additional favorable sites in which U-V minerals were concentrated likely existed upstream and downstream of the present depositional site. Unfortunately, at Bigrlyi, uplift on the basin margin has likely eroded upstream portions of the fluvial channel system, but other mineralized sites within the fluvial channel system might be traceable using a combination of palaeocurrent direction indicators and geophysical techniques that detect pyritic sandstone.

\subsection{Comparison with Colorado Plateau $U-V$ Deposits}

The Colorado Plateau U-V deposits have been known for over 120 years, and controls on mineralization were first discussed by Wright [40] and subsequently studied in the late 1950s and early 1990s. The most important tabular style deposits occur within the Jurassic Saltwash Member of the Morrison Formation, and other deposits are known in Triassic and Cretaceous sandstones. As tat Bigrlyi, tabular ore bodies are associated with fluvial channels in arkosic to micaceous sandstones. Unlike at Bigrlyi, mineralization here is often associated with an abundance organic plant matter [41,42]; organic matter-poor deposits are known but are less common. Furthermore, U-V mineralization does not always occur together; for example, the Jurassic Entrada Sandstone is dominated by V mineralization with only minor $U$ [40].

Vanadium minerals in the Colorado Plateau deposits commonly comprise hydrated oxides (e.g., montroseite, haggite, doloresite), vanadates (e.g., carnotite, tyuyamunite, pascoite) and phyllosilicates (roscoelite, V-hydrous mica, V-chlorite) and other rare minerals $[10,41,43]$. Haggite and montroseite are common in unoxidized ore, while doloresite is an indicator for the onset of oxidation. In the Saltwash-type deposits, the highest concentrations of $\mathrm{V}$ occur together with $\mathrm{U}$ mineralization, but $\mathrm{V}$ is distributed over a larger volume, and as with the Bigrlyi deposit, forms a halo around the deposit [13]. Other element distributions related to mineralization include the co-enrichment of S, Se, Mo and $\mathrm{Cr}$ in the mineralized zone [13], and the formation of authigenic calcite and dolomite stratigraphically above mineralization [7].

The genesis of Saltwash-type tabular U-V deposits is highly debated, particularly with regard to the relative timing of mineralization, the nature of diagenetic processes, the inferred fluid source(s), and the role of reductants including organic matter $[4,12,13,44]$. Northrop and Goldhaber [13] argue that mineralization formed at the interface between a relatively stagnant, evaporite-derived basinal brine and flowing meteoric water. On the other hand, Hansley and Spirakis [12] argue that the abundance and distribution of amorphous organic matter, in combination with diagenetic alteration processes of variable intensity, are crucial in the genesis of Saltwash-type deposits. Other works that invoke the importance of organic matter include Northrop and Goldhaber [13] and Wanty et al. [7].

The published work on the Colorado Plateau U-V deposits in general shows that these deposits have similar characteristics to those described for Bigrlyi, including ore mineralogy, vanadium distribution and abundance of carbonate cements engulfing ore zones, and the distribution of kaolinite [13]. 
However, there are differences, such as the lack of organic matter and sulfur depletion rather than enrichment; the timing and source of $\mathrm{V}$ mineralization is also interpreted differently. Northrop and Goldhaber [13] suggested that hypersaline brine played an important role in dolomite precipitation and ore formation. By contrast, the Bigrlyi carbonate mineral is predominantly evaporation-related calcite.

Uranium mineralization at Bigrlyi is strongly associated with detrital Fe-V-clays, which likely acted as reductants, but this has not been demonstrated in the Colorado Plateau deposits. Although V-bearing chlorite and chlorite-smectite (corrensite) are present in the Colorado Plateau deposits, they only appear to occur in the mineralized intervals, where they were interpreted to be authigenic phases formed as a result of $U$ mineralization [13].

Based mainly on the Colorado Plateau deposits, Finch and Davis [35] outlined nine diagnostic characteristics for Sandstone-hosted uranium deposits, including the Saltwash type. As considered below, it is instructive to compare how these characteristics might or might not apply to the Bigrlyi deposit. In the future, these characteristics may need to be modified to encompass a wider geographical range of deposits, and additional investigations of the Colorado Plateau deposits may be necessary to better clarify particular criteria. The lack of modern published petrographic/core imagery studies and geochemical data hinders any further detailed comparison with the Colorado Plateau deposits (Table 4).

Table 4. Comparison Bigrlyi Deposit-Finch and Davis Sandstone-hosted U-V Deposit Criteria.

\begin{tabular}{|c|c|}
\hline Criteria & Bigrlyi \\
\hline Host-rock unit is Silurian or younger in age. & Yes, Carboniferous \\
\hline $\begin{array}{l}\text { Host-rock unit was deposited most commonly in fluvial and } \\
\text { lacustrine environments in continental settings. }\end{array}$ & Yes \\
\hline $\begin{array}{l}\text { Provenance for sedimentation was commonly granitic or } \\
\text { felsic volcanic terranes, either of which provided a plausible } \\
\text { source for uranium. }\end{array}$ & Yes, granitic \\
\hline $\begin{array}{l}\text { Fossil carbonized plant matter or humic material is } \\
\text { commonly present. }\end{array}$ & $\begin{array}{l}\text { Only plant fossil imprints are present at Bigrlyi, organic } \\
\text { matter preservation was poor, and concentrations of organic } \\
\text { carbon are low. }\end{array}$ \\
\hline $\begin{array}{l}\text { Uranium concentrations were controlled by sedimentary } \\
\text { features rather than tectonic fracture structures. }\end{array}$ & $\begin{array}{l}\text { Yes, fluvial system architecture controls were important } \\
\text { at Bigrlyi }\end{array}$ \\
\hline $\begin{array}{l}\text { The host-rock units are those with good regional } \\
\text { transmissivity, and the deposits are localized where } \\
\text { sandstone/mudstone ratios are near } 1: 1 .\end{array}$ & $\begin{array}{l}\text { Good transmissivity aquifer characteristics were presumably } \\
\text { true for the pre-diagenetic sediments deposited at Bigrlyi, } \\
\text { and bounding shale units would have been important in } \\
\text { confining the original aquifer in grey sandstone. Although } \\
\text { mudstone lithic clasts are important sites for mineralization, } \\
\text { overall, mudstone is not as abundant as sandstone in } \\
\text { mineralized domains. Loss of permeability and porosity } \\
\text { occurred due to early diagenetic carbonate cementation. }\end{array}$ \\
\hline $\begin{array}{l}\text { Low-temperature groundwaters were the mineralizing } \\
\text { solutions, rather than high-temperature hypogene fluids. }\end{array}$ & $\begin{array}{l}\text { Yes, but earlier-formed detrital components are also present, } \\
\text { some could have been of original hydrothermal origin. }\end{array}$ \\
\hline $\begin{array}{l}\text { The ore minerals are epigenetic even though mineralization } \\
\text { was commonly part of diagenesis. }\end{array}$ & $\begin{array}{l}\text { No, mineralization was largely pre-diagenetic and there were } \\
\text { detrital components. }\end{array}$ \\
\hline $\begin{array}{l}\text { Mineralization took place in rocks having original low-angle } \\
\text { basin-ward dips, and in most cases the deposits were } \\
\text { preserved because of only slight increases in regional dip. } \\
\text { More severe tectonic events have redistributed ore in } \\
\text { some places. }\end{array}$ & $\begin{array}{l}\text { Yes and no, vertical tilting of the host sediments and } \\
\text { deformation at the basin margins did not appear to affect the } \\
\text { preservation of ore domains at Bigrlyi, but may have } \\
\text { initiated and been a driver for U redistribution. }\end{array}$ \\
\hline
\end{tabular}

\section{Conclusions}

In this contribution, the key features of the petrography, mineralogy and geochemistry of the Bigrlyi U-V sandstone-hosted deposit have been presented and discussed. Although the Bigrlyi deposit shares many of the features that characterize Saltwash-type tabular sandstone U-V deposits, as exemplified by those from the Colorado Plateau, there are a number of differences. In particular, the recognition of a role for detrital components in hosting U-V mineralization has led to the development of a new mineralization model. Following the multiple migration-accretion hypothesis of Gruner [34], the proposed mineralization model is envisaged as involving solution-precipitation 
processes, detrital transport, and U-V mineral preconcentration. It is hoped this work will encourage the further study and comparison of tabular, sandstone U-V deposits from around the world.

Supplementary Materials: The following are available online at http://www.mdpi.com/2075-163X/10/10/896/s1, Figure S1: XRD, Table S1: Bigrlyi whole-rock major and trace element geochemistry. Table S2: Bigrlyi Pb Isotope Data.

Author Contributions: All authors contributed to conceptualization, writing, visualization. All authors have read and agreed to the published version of the manuscript.

Funding: This research received no external funding.

Acknowledgments: Energy Metals Ltd. is thanked for supporting this project both financially and logistically, and for on-site support at the Bigrlyi camp by members of the exploration team over a number of field seasons.

Conflicts of Interest: The authors declare no conflict of interest.

\section{References}

1. Taylor, W.R.; Schmid, S. Bigrlyi uranium-vanadium deposit. In Australian Ore Deposits; Phillips, G.N., Ed.; The Australasian Institute of Mining and Metallurgy: Carlton, Australia, 2017; pp. 571-574.

2. IAEA. Geological Classification of Uranium Deposits and Description of Selected Examples; IAEA-TECDOC-1842; International Atomic Energy Agency: Vienna, Austria, 2018; p. 417.

3. Hostetler, P.B.; Garrels, R.M. Transportation and precipitation of uranium and vanadium at low temperatures, with special reference to sandstone-type uranium deposits. Econ. Geol. 1962, 57, 137-167. [CrossRef]

4. Finch, W.I. Geology of epigenetic uranium deposits in sandstone in the United States. US Geol. Surv. Prof. Pap. $1967,538,121$.

5. Grutt, E.W., Jr. Prospecting criteria for sandstone-type uranium deposits. In Uranium Prospecting Handbook; Bowie, S.H.U., Davis, M., Ostle, D., Eds.; IMM: London, UK, 1972; pp. 47-77.

6. Lee, S.Y.; Baik, M.H.; Lee, Y.B. Adsorption of uranyl ions and microscale distribution on Fe-bearing mica. Appl. Clay Sci. 2009, 44, 259-264. [CrossRef]

7. Wanty, R.B.; Goldhaber, M.B.; Northrop, H.R. Geochemistry of Vanadium in an Epigenetic, Sandstone-Hosted Vanadium-Uranium Deposit, Henry Basin, Utah. Econ. Geol. 1990, 85, 270-284. [CrossRef]

8. Shawe, D.R. Uranium-Vanadium Deposits of the Slick Rock District, Colorado. US Geol. Surv. Prof. Pap. 2011, 576-F, 80 .

9. Sanford, R.F. A Quantitative Model of Ground-Water Flow during Formation of Tabular Sandstone Uranium Deposits. Econ. Geol. 1994, 89, 341-360. [CrossRef]

10. Breit, G.N. Origins of Clay Minerals Associated with V-U Deposits in the Entrada Sandstone, Placerville Mining District, Southwestern Colorado. Econ. Geol. 1995, 90, 407-419. [CrossRef]

11. Breit, G.N.; Goldhaber, M.B. Hematite-enriched sandstones and chromium-rich clays-Clues to the origin of vanadium-uranium deposits in the Morrison Formation, southwestern Colorado and southeastern Utah, U.S.A. In IAEA-TECDOC-500; International Atomic Energy Agency: Vienna, Austria, 1989; pp. 201-226.

12. Hansley, P.L.; Spirakis, C.S. Organic matter diagenesis as the key to a unifying theory for the genesis of tabular uranium-vanadium deposits in the Morrison Formation, Colorado Plateau. Econ. Geol. 1992, 87, 352-365. [CrossRef]

13. Northrop, R.H.; Goldhaber, M.B. Genesis of the Tabular-Type Vanadium-Uranium Deposits of the Henry Basin, Utah. Econ. Geol. 1990, 85, 215-269. [CrossRef]

14. Wells, A.T.; Moss, F.J. The Ngalia Basin, Northern Territory: Stratigraphy and Structure. Bur. Miner. Resour. Bull. 1983, 212, 88.

15. Lindsay, J.F. Supersequences, suberbasins, supercontinents-Evidence from the Neoproterozoic-Early Palaeozoic basins of central Australia. Basin Res. 2002, 14, 207-223. [CrossRef]

16. Haines, P.W.; Hand, M.; Sandiford, M. Palaeozoic synorogenic sedimentation in central and northern Australia: A review of distribution and timing with implications for the evolution of intracontinental orogens. Aust. J. Earth Sci. 2001, 48, 911-928. [CrossRef]

17. Lipski, P. Structural configuration and petroleum play potential of the Ngalia Basin. Abstr. Geol. Soc. Aust. 2000, 60, 61-63. 
18. Schmid, S.; Foss, C.; Hill, J.; Quigley, M.; Schaubs, P.; Cleverley, J.; Robinson, J. JSU Ngalia Basin Uranium Mineral System Project (CSIRO EP114951); NTGS Record 2012-003; Northern Territory Geological Survey: Darwin, Australia, 2012; p. 97.

19. Shaw, R.D. Structure and Tectonic Development of the Mount Doreen 1:250,000 Sheet Area; AGSO Record 1994/54; Australian Geological Survey Organisation: Canberra, Australia, 1994; p. 78.

20. Walter, M.R.; Veevers, J.J.; Calver, C.R.; Grey, K. Neoproterozoic stratigraphy of the Centralian Superbasin, Australia. Precambrian Res. 1995, 73, 173-195. [CrossRef]

21. Maidment, D.W.; Williams, I.S.; Hand, M. Testing long-term patterns of basin sedimentation by detrital zircon geochronology, Centralian Superbasin, Australia. Basin Res. 2007, 19, 335-360. [CrossRef]

22. Sandiford, M.; Hand, M. Controls on the locus of intraplate deformation in central Australia. Earth Planet. Sci. Lett. 1998, 162, 97-110. [CrossRef]

23. Kositcin, N.; Beyer, E.E.; Whelan, J.A.; Close, D.F.; Hallett, L.; Dunkley, D.J. Joint NTGS-GA Geochronology Project: Arunta Region, Ngalia Basin, Tanami Region and Murphy Province July 2011-June 2012; NTGS, Record 2013-004; Northern Territory Geological Survey: Darwin, Australia, 2013; p. 39.

24. Deckelmann, J.A.; Davidson, J.K. A closer look at the petroleum potential of the Ngalia Basin, Northern Territory. Pet. Expl. Soc. Aust. J. 1994, 92-100.

25. Fidler, R.W.; Pope, G.J.; Ivanac, J.F. Bigrlyi uranium deposit. In Geology of the Mineral Deposits of Australia and Papua New Guinea; Hughes, F.E., Ed.; Monograph 14; Australasian Institute of Mining and Metallurgy: Carlton, Australia, 1990; pp. 1135-1138.

26. Energy Metals. December Quarterly Report to Shareholders. 2019, p. 24. Available online: https: //www.asx.com.au/asxpdf/20191204/pdf/44c93djjvj0gyg.pdf (accessed on 5 October 2020).

27. Schmid, S.; Quigley, M.A. Fluvial architecture and diagenesis of the Mt Eclipse Sandstone, northern Ngalia Basin, Australia. Aust. J. Earth Sci. 2014, 61, 1081-1094. [CrossRef]

28. Kerr, S.; Liu, J. Ngalia Regional Project, Group Annual Report, GR070-09_GA_01; NTGS Minerals Exploration Reports; Northern Territory Geological Survey: Darwin, Australia, 2015; p. 51.

29. Raven, M.D.; Gomez-Camacho, R.; Qian, G. Quantitative XRD Analysis of Uranium Host Rocks from the Bigrlyi Project, CSIRO Report No. D2559; NTGS Minerals Exploration Reports, CR2012-1253; Northern Territory Geological Survey: Darwin, Australia, 2012; p. 24.

30. Goldhaber, M.B.; Reynolds, R.L. Origin of Marcasite and Its Implications Regarding the Genesis of Roll-Front Uranium Deposits; U.S.G.S. Open File Report 79-1696; United States Geological Survey: Reston, VA, USA, 1979; p. 40.

31. de Nooy, D. ALS-Ammtec Quantitative Automated Mineralogical Analysis, Report No. MIN1081(E); NTGS Minerals Exploration Reports, CR2012-1253; Northern Territory Geological Survey: Darwin, Australia, 2012; p. 59.

32. Grant, J.A. The Isocon Diagram-A Simple Solution to Gresen's Equation for Metasomatic Alteration. Econ. Geol. 1986, 81, 1976-1982. [CrossRef]

33. Energy Metals. March Quarterly Report to Shareholders. 2018, p. 11. Available online: https://www.asx.com. au/asxpdf/20180430/pdf/43tmw7z60kzvwy.pdf (accessed on 5 October 2020).

34. Gruner, J.W. Concentration of Uranium in Sediments by Multiple Migration-Accretion. Econ. Geol. 1956, 51, 495-520. [CrossRef]

35. Finch, W.I.; Davis, J.F. Sandstone-Type Um Deposits. In An Introduction in Geological Environments of Sandstone-Type Uranium Deposits; IAEA Technical Document 328; International Atomic Energy Agency: Vienna, Austria, 1985; pp. 11-20.

36. Richards, J.P.; Kerrich, R. The Porgera gold mine, Papua New Guinea; magmatic hydrothermal to epithermal evolution of an alkalic-type precious metal deposit. Econ. Geol. 1993, 88, 1017-1052. [CrossRef]

37. Latta, D.E.; Boyanov, M.I.; Kemner, K.M.; O'Loughlin, E.J.; Scherer, M.M. Abiotic reduction of uranium by Fe(II) in soil. Appl. Geochem. 2012, 27, 1512-1524. [CrossRef]

38. Wersin, P.; Hochella, M.F.; Persson, P.; Redden, G.; Leckie, J.O.; Harris, D.W. Interaction between aqueous uranium (VI) and sulfide minerals: Spectroscopic evidence for sorption and reduction. Geochim. Cosmochim. Acta 1994, 58, 2829-2843. [CrossRef]

39. Bullock, L.A.; Parnell, J. Selenium and molybdenum enrichment in uranium roll-front deposits of Wyoming and Colorado, USA. J. Geochem. Explor. 2017, 180, 101-112. [CrossRef] 
40. Wright, R.J. Ore controls in sandstone uranium deposits of the Colorado Plateau. Econ. Geol. 1955, 50, 135-155. [CrossRef]

41. Weeks, A.D. Mineralogy and geochemistry of vanadium in the Colorado Plateau. J. Less Common Met. 1961, 3, 443-450. [CrossRef]

42. Fischer, R.P.; Stewart, J.H. Copper, vanadium and uranium deposits in sandstone-Their distribution and geochemical cycles. Econ. Geol. 1961, 56, 509-520. [CrossRef]

43. Meunier, J.D. The composition and origin of vanadium-rich clay minerals in Colorado Plateau Jurassic Sandstones. Clays Clay Miner. 1994, 42, 391-401. [CrossRef]

44. Evans, H.T., Jr.; Garrels, R.M. Thermodynamic equilibria of vanadium in aqueous systems as applied to the interpretation of the Colorado Plateau ore deposits. Geochim. Cosmochim. Acta 1958, 15, 131-149. [CrossRef]

Publisher's Note: MDPI stays neutral with regard to jurisdictional claims in published maps and institutional affiliations.

(C) 2020 by the authors. Licensee MDPI, Basel, Switzerland. This article is an open access article distributed under the terms and conditions of the Creative Commons Attribution (CC BY) license (http://creativecommons.org/licenses/by/4.0/). 